\title{
Covid-19 Pandemisi, Siyasi Rejimler ve Liberal Demokrasi
}

\author{
DOI: 10.26466/opus.885216
}

*

\author{
Mehtap Söyler * - Mustafa Agah Tekindal ** \\ * Dr. Öğretim Üyesi, İzmir Kâtip Çelebi Üniversitesi/İktisadi ve İdari bilimler Fak., İzmir/Türkiye \\ E-Posta: mehtap.soyler@ikcu.edu.tr \\ ORCID: 0000-0003-0243-3240 \\ ** Doç.Dr., İzmir Kâtip Çelebi Üniversitesi/Tıp Fakültesi, İzmir/Türkiye \\ E-Posta: matekindal@gmail.com \\ ORCID: 0000-0002-4060-7048
}

\section{Öz}

Bu makale, siyasi rejimler ve liberal demokrasilerin Covid-19 pandemisi ile etkileşimini çeşitli yaklaşımlar ve tekniklerle araştırmıştır. İlk olarak, 2019-2021 arasında Web of Science veri tabanında taranan Covid-19 pandemisi ve siyasi rejimlerle ilgili çalışmalar bibliyometrik analizle incelenmiştir. Araştırma alanına dair kavram haritasında demokrasinin merkezi ve yön verici kavram olduğu; kutuplaşma, toplumsal cinsiyet, demokratik açıktan oluşan üç konu kümesinin farklı ölçüde kendi içinde yoğunlaşmış, gelişmiş olsalar da birbirine yakın derecede merkezileştĭ̆i, diğer konularla bağlantı kurduğu tespit edilmiştir. Sankey Diyagramı ABD adresli eserlerin literatürün oluşmasında etkili olduğunu göstermiştir. İkinci olarak makale, bibliyometrik analiz sonucundan yola çıkarak pandemi ve demokrasi etkileşimine odaklanmış, ekonomik gelişmişlik düzeyleri yüksek liberal demokrasiler olan G7 ülkelerinin pandemiyle mücadelesini mercek altına almıştır. Bayesci (önsel) meta-analizde Freedom House Endeksi verileriyle Dünya Sağllk Örgütü'nün pandemi vaka ve vefat sayılarından oluşan birliktelik modeli orta düzeyde uyumludur, etkileşim gücü yüksektir. Meta-analizin sonraki çalışmalar için temel oluşturabileceği öngörüsüne ulaşılmıştır. Son olarak, G7 ülkelerinde demokrasinin pandemi sınavı değgerlendirilmiştir. Demokrasinin Çeşitleri Projesi'nin Pandemiyle Bağlantılı İhlaller ve Gerileme endeksleri incelenmiş, sadece ABD'de epey ihlal kaydedildiği ve demokraside gerilemenin yüksek düzeyde olduğ u saptanmıştır. Bulgular ışı̆̆ında, siyasi rejimlerle pandeminin kesiştiğ i alandaki çalışmaların takip edilmesi ve endekslerdeki kavramsallaştırmanın değişen koşullar uyarınca gözden geçirilmesi önerilmiştir.

Anahtar Kelimeler: Covid-19, siyasi rejimler, liberal demokrasi, bibliyometrik analiz, Bayesci önsel meta-analiz, endeksler 


\title{
Covid-19 Pandemic, Political Regimes, and Liberal Democracy
}

\begin{abstract}
This article aims at studying the interaction between Covid-19 pandemic, political regimes and liberal democracies through diverse methods. Firstly, it conducts bibliometric analysis of works on the Covid19 pandemic and political regimes indexed in Web of Science dataset between 2019 and 2021. The conceptual map on this research area demonstrates that democracy is the central and motor theme. Three conceptual sets comprising polarization, gender, and democratic deficit share similar levels of centrality or external links to other concepts, despite their differing levels of density or internal links. The Sankey diagram shows that authors from institutions based in the USA were influential in the making of this research area. Secondly, since democracy emerges as the motor theme in the bibliometric analysis, this article focuses on the interaction between the pandemic and democracy. It sheds light on the struggle against the pandemic in G7 countries, liberal democracies with high levels of economic development. Bayesian (prior) meta-analysis examines the association between the level of Covid-19 cases as well as deaths according to the World Health Organization and the aggregate level of political rights and civil liberties according to Freedom House Index. The association model resulting from meta-analysis indicates medium-level goodness of fit and high-level effect size, which leads to the prediction that this analysis could be a basis for further studies. Lastly, this article critically assesses G7 countries' democratic performance at the "pandemic exam" by evaluating the Pandemic Violations and Backsliding Indices of Varieties of Democracy Project. The USA is the only country with some, or considerable violations of democratic standards and high levels of pandemic backsliding compared to other G7 countries. In the light of these findings, it is suggested that research at the intersection of political regimes and the pandemic should be tracked and the conceptualization embedded in indices should be revised in accordance with changing conditions.
\end{abstract}

Keywords: Covid-19, political regimes, liberal democracy, bibliometric analysis, Bayesian priormeta-analysis, indices 


\section{Giriş}

Maske takma ve mesafe zorunluluğunun gündelik hayatımızın bir parçası olduğu karantina günlerinde, bildiğimiz dünyanın sona erdiğini hayatın her alanında deneyimlemekteyiz. Dünya Sağllk Örgütü'nün istatistik verilerine göre, 21 Şubat 2021 itibariyle Covid-19 pandemisinden dolayı hayatını kaybedenlerin sayıs 2.446.008, teyit edilebilen toplam hasta sayıs 110.384.747, yeni vakaların sayıs1 381.841'dir (WHO, 2021). Covid-19 sadece bir pandemi değil, sosyo-ekonomik sonuçları bakımından II. Dünya Savaşı'ndan bu yana yaşanmış en büyük ekonomik krizdir. Covid-19 küresel bir salgın olmakla birlikte, bu salgının sosyo-ekonomik sonuçları II. Dünya Savaşı'ndan beri yaşanmamış bir ekonomik krize yol açmıştır. Sağlık hizmetlerine erişim maliyetinin yüksek olduğu, sağlık kurumlarının verimli olmadığ 1 ülkelerde krizin en önemli sonucu insan kaybının artması olmuştur. Pandemi, tüm sektörlerde üretimi yavaşlatmış ve küresel ekonomiyi her alanda bir darboğaza sokmuştur. Yaklaşık bir yıl içerisinde kişi başına düşen gelir sert bir azalma kaydetmiş ve milyonlarca insan yoksullaşmıştır. Aşırı yoksulluk dünyada yayılmış ve 88 milyon kişi daha aşırı yoksulluk içinde yaşamaya başlamıştır. Dünya Bankası ekonomik küçülme daha da kötüleşirse, bu sayının 115 milyona çlkabileceğini ve 2021'de 143-163 milyon kişiye ulaşılabileceğini tahmin etmiştir (Wadhwa ve Blake, 2021). Birleşmiş Milletler Gida ve Tarım Örgütü'ne göre gıda güvensizliği, yetersiz beslenenlerin sayısına 83 milyon ile 132 milyon arasında insanın eklenmesine yol açacaktır (UN Food and Agriculture Organization, 2021).

Bilim insanlarının Covid-19 ile mücadelede sürü bağışıklı̆ğ için kritik öneme sahip olduğunu ifade ettikleri aşılamada elde edilen başarılara rağmen, üçüncü dalgada aşılamada ilerleme sadece aşı tedariki nedeniyle değil aşıya güven, üreticilere güven ve sağlık sistemine güven gibi faktörler nedeniyle de yavaştır (Wong vd., 2021). Mutasyona uğrayan ve varyantları gelişen virüsün bulaşma hızının artmasının da etkisiyle vaka ve vefat sayıları aşılamaya rağmen artmaktadır (WHO, 2021). Önü alınamayan bir küresel ekonomik gerileme döneminde siyasi rejimler ve pandemi arasındaki etkileşim nasıl olmuştur? Bu soruyu yanıtlamadan önce pandemi öncesinde, 2020 yılına kadar siyasi rejimlerin gelişimine göz atmak faydalı olacaktır. Huntington (1991) tarihsel anlamda üç "demokratikleşme dalgası" tespit etmiştir. İlk demokratikleşme dalgasını (1828-1926) bir otokratikleşme dalgası (1922-1942) 
takip etmiş, ikinci demokratikleşme dalgasını (1943-1962) ikinci otokratikleşme dalgası (1958-1975) takip etmiştir. Huntingon, 1974'ten itibaren üçüncü dalganın başladığını ve Soğuk Savaş'ın bitimiyle dalganın belirgin bir şekilde yükseldiğini öne sürmüştür.

2017 yılında Demokrasinin Çeşitleri Projesi'nin (Varieties of Democracy Project, $V$-Dem) 178 ülkenin ortalama demokrasi değerlerini yayınladıkları raporuna göre, 1974'ten 2005 yılına kadar devam eden demokratikleşme dalgası durgunlaşma döneminden sonra yerini 2009 'dan itibaren bir otoriterleşme dalgasına bırakmıştır. 2017' de dünya nüfusu yaklaşık 7,5 milyar iken otokratikleşen rejimlerin olduğu ülkelerde yaşayan insanların sayısı 2,5 milyardır. 2012-2018 arasında geçen 6 yıl içerisinde, genel anlamda 25 yıl öncesine, 1991'de Sovyetler Birliği'nin dağılmasından sonraki değerlere geri dönülmüştür. Gerileme en çok basın özgürlüğü ve ifade özgürlüğü haklarının çı̆gnenmesi ve hukukun üstünlügü ilkesinin gereklerinin yerine getirilmemesi nedeniyle yaşanmıştır. Demokratik gerileme Batı ve Doğu Avrupa'da ile Amerika Birleşik Devletleri'nde yürütme gücünün yetkilerini genişletme suretiyle gerçekleşmiştir. Nüfusa oranladığımızda, Batı Avrupa ve Kuzey Amerika' da demokratik hak ve özgürlükler 40 yıl önceki liberal demokrasi değerlerine geri dönmüştür (Lührmann vd., 2018, s.1322-1325).

Pandemiden önce, otokratikleşme dalgası hızlanmış ve derinleşmiştir. 2001 yılında 98 devlet ve toprak parçasında (territory) dünya nüfusunun \%55'i demokrasilerde yaşarken, 2019 yılında dünyada 87 ülkede dünya nüfusunun \%46'sı seçimsel (electoral) ve liberal demokrasilerde yaşamaktadır. Sadece 2018 yılında 8 ülkede demokrasi çökmüştür. Buna karşılık, 2019 yılı sivil toplumun otoriter eğilimlere sahip 22 ülkede demokrasi standartlarını iyileştirmek için harekete geçtiği bir "protesto yllı" olmuştur. Covid-19 küresel anlamda sosyal eşitsizliklerin daha da belirginleşmesine neden olmuştur. Bununla birlikte, bazı hükümetlerin pandemiden kaynaklı olağanüstü koşulların gerektirdiği kısıtlamaları genişleterek kişilerin dolaşım özgürlüğü ve örgütlenme hakkını kısıtlaması, ifade özgürlügü ve basın özgürlüğünü daha çok ihlal etmesi protestoların yayılma ihtimaline işaret etmektedir (Maerz vd., 2020).

Sosyo-ekonomik koşullar siyasi rejimleri ve dolayısıyla rejimlerin krizlerle baş etme yeteneğini etkilemektedir. Seymour Martin Lipset'in (1959) “Demokrasinin Toplumsal Gereklilikleri: Ekonomik Kalkınma ve Siyasal Meşru- 
iyet" başlıklı makalesi demokrasinin sosyo-ekonomik koşullarına dair literatürün gelişmesinde öncülük etmiştir. "Lipset hipotezi” ekonomik gelişmenin demokrasiye içselliğini (endogeneous) öne sürer. Bu hipotez bugüne dek siyasi rejim ve siyasi ekonomi literatüründe çok tartışılmış ve yeniden formüle edilmiş olmakla birlikte çok teyit edilen, sosyo-ekonomik koşullar hipotezi sağlamlığını kanıtlamıştır. Bu hipotezdeki içsellik argümanını sorgulayan çalışmalar (Przeworski vd., 2000) ekonomik gelişmenin ancak demokrasiye geçişten sonra istikrarı sağladığına dair bulgular ortaya koymuş olsa da ekonomik değerlerin istikrarlı demokrasileri açıkladığına dair tez halen sağlamlığını korumaktadır. Ayrıca, Acemoğlu ve arkadaşlarının 1960-2010 yıllarını kapsayan bir çalışması, demokrasiye geçişten sonra kişi başına düşen gayrı safi yurt içi hasılanın uzun vadede, demokrasiye geçişten 25 yıl sonrasında otoriter rejimlere göre \%20 fazla olduğunu ve demokrasinin ekonomik büyümeye olumlu etkisinin bulunduğu bulgusuna ulaşmıştır (Acemoğlu vd., 2019).

Bu makale, Covid-19 pandemisi bağlamında siyasal rejimleri ve liberal demokrasiyi farklı yöntemsel tekniklerin sunduğu bulgular ışığında incelemektedir. İlk olarak, araştırmamız pandemiyle siyasi rejimlerin kesiştiği alan hakkındaki literatürde ön plana çıkan konu ağlarını bibliyometrik analizle görselleştirerek sunmaktadır. Bibliyometrik analizde, siyasi rejimler ve Covid-19 pandemisi hakkında 2019-2021 arasında WoS (Web of Science) veri tabanındaki bibliyografik verilerin RStüdyo Bibliometrix programiyla kavramsal analizi yapılmaktadır. Covid-19 pandemisi ve siyasi rejimlerin kesiştiği araştırma alanı bibliyometrik analizle incelenirken analitik anlamda demokrasinin motor ve yön verici bir konu olduğu saptanmıştır. Bibliyometrik analize tabi tutulan eserlerde demokrasinin konumu, hangi kavramların ne sıklıkla bir araya geldiği ve yön verici olduğu, hangi kavram kümelerinin gelişmiş, kendi içinde yoğun bağlantılar kurmuş olduğu ve hangilerinin daha çok başka kavramlarla bağlantılı olduğu ortaya konmuştur. 2019 yılından beri gelişen literatürdeki eser başlıkları, anahtar kelimeler ve yazarların kurum bilgisindeki ülkeler arasındaki bağlar değerlendirilmiştir.

İkinci ve üçüncü bölümlerde çalışmamız demokratik rejimleri mercek altına tutmakta, ekonomik gelişmişlik ve demokrasi düzeyleri yüksek liberal demokrasiler olan G7 ülkelerine odaklanmaktadır. İkinci bölüm pandemi ve siyasi rejim etkileşimini bu liberal demokrasiler örneğinde Bayesci meta-analizle bir ön değerlendirmeye tabi tutmaktadır. Bayesci (önsel) meta-analizde 2020 yılı Freedom House Endeksi verileriyle Dünya Sağlık Örgütü' nün resmi 
olarak açıkladığı kümülatif vaka ve vefat sayılarından oluşan birliktelik modelinin (association model) uyumu ve etki gücü analiz edilmektedir. Amaç birlikteki etki gücünü belirlemek amacıyla önsel bir bilgi edinmektir. Ekonomik gelişmişlik ve demokrasi düzeyleri yüksek liberal demokrasiler olan G7 ülkelerinin Covid-19 pandemisiyle daha iyi mücadale etmesi, bunun vaka sayılarına yansıması beklenir. Pandemiyle mücadelede başarı en önemli insan hakkı olan yaşama hakkını korumada başarı olarak da değerlendirilebilir. Üçüncü bölüm, G7 ülkelerinin pandemiyle bağlantılı demokrasi karnesini gözden geçirmektedir. Çalışmamız Covid-19 pandemisinin yarattı̆̆1 yeni dünyada G7 ülkeleri örneğinde liberal demokrasilerin Freedom House ve $V$ Dem Projesi'nin Pandemiyle Bağlantılı İhlaller ve Gerileme endekslerinin verilerini incelemektedir. Bibliyometrik analizin sonuçları ve endekslerin verileri karşılaştırıldıktan sonra, aradaki farklardan yola çıkılarak, endekslerde eksik unsurların tespit edilmesine yönelik öneriler sunulmaktadır.

\section{Bibliyometrik Analiz: COVID-19 Pandemisi ve Siyasi Rejimler}

\section{Yöntem}

Bu bölümde, WoS Core Collection veri tabanında siyasi rejim ve Covid-19 pandemisi ile ilgili yayınları RStüdyo Bibliometrix programıla kavram analizi yapılmıştır. Bibliyometri bilimsel üretimi, literatürü ölçme ve analiz etmeyi hedefleyen bilimmetrinin (scientometrics) alt dalıdır. Bibliyometri bilgi sistemleri, bilgi teknolojisi ve sosyolojisi gibi alanlarla pek çok bakımdan örtüşen araştırma sorularını ele alır. Bibliyometrik analiz bibliyografik verilerin bilimsel yayınların matematiksel ve istatistiksel tekniklerin uygulanmasıyla ölçülmesini amaçlar. Belli bir konuda bilimsel yazının nasıl geliştiği, yayınlardaki kelimelerin hangi sıklıkla tekrar ettiği, belli kelimelerin eş zamanlı ortaya çıkma sıklığı tespit edilebilir. Araştırmacılar arasında gelişen işbirliği ağları, yayın ve atıf sayısı, atıf örüntüleri, hangi eserlere hangi sıklıkla aynı anda atıf yapıldığı ölçülebilir (Petersohn ve Heinze, 2018).

$\mathrm{R}$, istatistiksel programlama dili olmanın yanında, bu dille istatistiksel hesaplama ve grafikler için yazılım geliştirme ortamıdır. R gibi erişime açık kaynak olan RStüdyo, bu dil için entegre yazılım geliştirme ortamı ve grafiksel kullanıcı arayüzüdür. Bibliometrix, veri analizi ile bilimsel haritalama aracılığıyla bulguların görselleştirilmesinde kullanılmaktadır. Bibliometrix yazılım 
programı Biblioshiny uygulaması ile internet tarayıcısinda bibliyometrik analiz yapma fırsatı sunmaktadır. Veri toplama, veri tabanlarından elde edilen bibliyografik verilerin belli formatlarda Biblioshiny uygulamasına yüklenmesi aşamasıdır. Veri analizi analiz birimlerine (kaynak, yazar veya dokümanlara) odaklanabilir. Veri analizi aşamasında, doküman ve niteliklerden (attribute) matriks oluşturulur, veri indirgeme ve ağ matriksiyle betimleyici analiz yapilır. Bibliometrix veri indirgeme yoluyla kelimelerin kümelenme ve birlikte kullanılma sıklığını ölçer; ağ matriksi oluşturma yoluyla bibliyografik eşleme, atıflar, ortak atıflar (co-citation), yazarlar arası işbirliği ve tarihsel gelişim analizlerini yapar. Veri indirgeme yoluyla elde edilen betimleyici analiz sonuçları diyagramlar ve haritalarla görselleştirilebilir. Araştırmacı ağı matriksinin bulgularıyla ağ haritası ve tarihsel haritalar görselleştirilebilir. Örneğin, incelediğimiz araştırma alanında hangi dergilerin en çok yayın çıkardığı, hangi ülkelerden hangi yazarların bu alanda ön plana çıktığı ve en çok hangi makalelerin alıntılandığı, eser veya yazar ortak atıfları analiz edilebilir (Aria ve Cuccurullo, 2017).

Bibliometrix program1, veri analizinde kavramsal, entelektüel ve sosyal yapıya dair bulguların elde edilip görselleştirilmesini sağlar. Kavramsal yapı araştırılan konuda bilim camiasının hangi kavramları kullandı̆̆ını, konuyla ilgili diğer konuların literatürdeki rolünü ve temel eğilimleri yansıtır. Programın kavram yapısı analizinde uyguladığı istatistiksel teknikler ağ analizi, etkensel analiz, tematik haritalama, tematik evrim ve konu modellemedir. Entelektüel yapı hangi yazarların hangi eserlerinin bilimsel camiayı araştırılan konuda etkilediğini atıfların analizi aracılı̆̆ıyla yansıtır. Entelektüel yapı analizinde uygulanan istatistiksel teknikler ağ analizi ve tarihsel analizdir. Sosyal yapı ise, yazarlar, çalıştıkları veya araştırma desteği aldıkları kurumlar ve ülkeleri, yazarlar arasında işbirliğini ve etkileşimi yansıtır. Kavramsal yapı analizinde farklı analiz birimlerinde (anahtar kelimeler, doküman başlığı, öz ve tam doküman) hangi kelimelerin hangi sıklıkla bir araya geldiği hesaplanır. Entelektüel yapı analizinde amaç atıf ve ortak atıfların, yazarlar ve yayınlar bazında hesaplanmasıdır. Sosyal yapı analizinde amaç, yazarlar arasında işbirliğinin, eş-yazarlıkların, araştırmacıların hangi kurumlar aracılığıyla işbirliği yaptığının ve ortak yayınların analiz edilmesidir. Sosyal yapı analizinde uygulanan istatistiksel teknikler işbirliği ve ağ analizidir (Aria ve Cuccurullo, 2020). 
Bibliyometrik analiz için ilk olarak, WoS Core Collection veri tabanından siyasi rejim ve Covid-19 pandemisi üzerine yayınların tüm bibliyografik verileri (kaynak adı, başlık, yazar, öz, anahtar kelimeler, alıntılanan kaynaklar, vb.) toplanmıştır. WoS arama motorunda taranacak yayınlar konu ve alan bakımından sınırlandırılmıştır. WoS'ta ileri arama yapmak için VE, VEYA (AND, OR) gibi Boole cebrindeki semboller kullanılır (WoS, 2020). ${ }^{1}$ Bibliyometrik verinin (corpus) kapsamasını istediğimiz kümede neler olduğuna bağlı olarak arama formülünü oluştururuz. Pandemi ve siyasi rejimler üzerine inceleme yaptığımız için önce her değişkene karşlık gelen muhtemel kelimeleri bir birleşim kümesi oluşturacak şekilde VEYA ile birleştirmemiz gerekmiştir. Sonra bu kümeleri VE bağlacı ile kesiştirerek kesişim kümesini alırız. WoS tarafından sunulan bilimsel alan kategorilerinden Siyaset Bilimi, Uluslararası İlişkiler ve Bölge Çalışmaları alanlarının da birleşim kümesini aldıktan sonra, diğer kümelerle kesişim kümesini bulmak için VE bağlacını kullanırız. WoS alan etiketleriyle TS konu seçiminde, WC ise kategori, yani alan seçiminde kullanılır. Bibliyografik veriler 5 Şubat 2021 tarihinde WoS veri tabanından şu sorgu ile çekilmiştir: TS=(Covid OR Covid 19 OR pandemic) AND TS=(political regime OR democracy OR authoritarianism OR authoritarian OR democratic) AND WC $=$ (political science OR international relations OR area studies). ${ }^{2}$ Daha sonra, HIV/AIDS veya ebola üzerine yayınların sonucu etkilememesi için kontrol sağlanmış, bu yayınların 2019 öncesine ait olduğu saptanmış olduğu için 2019, 2020 ve 2021 yıl sınırlaması yapılmıştır. Covid-19 pandemisinin 2019 yılından itibaren etkisini gösterdiği göz önünde bulundurularak 2019 tarihli Avustralya üzerine iki yayın dahil edilmiştir.

Sorgu sonucunda 136 yayının bibliyometrik verisi elde edilmiştir. Veriler düz metin formatına dönüştürüldükten sonra temizleme ve düzeltme işlemleri yapılmıştır. Analizde hatalı bulgulara yol açacak kelimeler (and, of, the, vb.) temizlenmiştir. Veri setinde hatalı veriler düzeltilmiştir. RStüdyo programında Bibliometrix programı çalıştırıldıktan sonra veriler Biblioshiny uygulamasına aktarılmışır. İlk olarak kavramsal haritalama ile konu analizi yapıl-

\footnotetext{
${ }^{1}$ Küme kuramıyla Boole cebrindeki sembollerden VE kesişim kümesini, VEYA birleşim kümesini sembolize eder.

${ }^{2}$ TS=(Covid VEYA Covid 19 VEYA pandemi) VE TS=(siyasi rejim VEYA demokrasi VEYA otoriteryanizm VEYA otoriteryan VEYA demokratik) VE WC=(siyaset bilimi VEYA uluslararası ilişkiler VEYA bölge çalışmaları)
} 
mıştır. İkinci olarak, Sankey Diyagramı'yla bibliyografik verilerde farklı parametreler ele alınarak birbirleriyle nasıl bağlantı içinde oldukları veya nasıl geliştikleri hakkında içerme endeksi (inclusion index) meydana getirilmiştir.

Kavramsal yapı hangi araştırma gündeminde hangi konuların hem önemli hem de güncel olduğunu ortaya çıkarır. Bu makalede 2019-2021 yılları kısa bir süreyi kapsadığından konunun tarihsel gelişimi analize dahil edilmemiştir. Bibliyografik verilerde yer alan özet, anahtar kelimeler ve başlık analiz birimlerinde yer alan kelimelerin analiziyle bu kelimelerin eş zamanlı bir aradalık ağı, yani eşdizimlilik ağı (co-occurrence network) tespit edilmiştir. Bibliyografik veri setindeki kelimeler arasında, yakınlık degerleri yuiksek kelimelerin kümelenmesi es,dizimlilik matrislerini oluşturur. Kelimelerin birbirlerine benzerliği, yakınlığı denklik (equivalence) değeridir. Konu veya kavram haritası, bir araştırma alanındaki eserlerde geçen, eşdizilim ağında birbiriyle yakın kelimelerden oluşan kümelerin Callon merkezilik ve yoğunluk analizidir (Callon vd., 1991), stratejik diyagramlar halinde görselleştirilir. Şekil 1'deki kavram haritasında, balonların her biri eşdizimlilik ağ kümesini temsil eder. Balonun başlığı olan kelime, ağ kümesinde en sık geçen kelimedir. Balonun büyüklüğü kümedeki kelimelerin sıklığına bağlıdır. Merkezilik, kümenin başka kümelerle bağlantısını, araştırma alanı için ne kadar önemli olduğunu gösterir; yoğunluk ise kümenin içindeki kelimelerin bağlantı yoğunluğunu, konunun gelişim derecesini gösterir.

Şekil 1'deki kavramsal haritanın sağ üst çeyreği merkezi ve yoğun konuları içerir. Motor konular, araştırma alanında önemli, yön verici literatürün dayandığı konulardır. Haritanın sağ alt çeyreğinde, merkezi ama yoğunluk düzeyi düşük konular bulunur. Bu çeyrekteki konu kümeleri, alandaki diğer konularla kesişen temel konular olmakla birlikte kendi içinde gelişmemişlerdir. Sol alt çeyrekte araştırma alanıyla ilgili literatürde yeni gelişmeye başlayan ya da popülerliği düşen konular bulunur. Bunlar hem merkezilik hem yoğunluk bakımından düşüktür. Sol üst çeyrekte, gelişmiş ama kendine has konular vardır. Bu çeyrekteki konuların kendi kümesindeki konular arasında etkileşimi yoğundur, ama merkeziliği düşüktür, yani diğer konularla ilgisi önemsizdir, etkileşimi azdır. Şekil 2‘deki Sankey Diyagramı' yla eserlerin bibliyografik verilerinde WoS anahtar kelimeleri (Keyword Plus), yazarların adreste belirttikleri ülkeler ve eser başlıkları analiz birimleri incelenerek içerme endeksi görselleştirilmiştir. Bağı gösteren kanalların kalınlığı paylaşılan ortak 
kelime sayısına bağlı olarak kalın (yüksek sıklık) veya incedir (düşük sıklık) (Aria vd., 2020, s. 20-25).

\section{Bulgular}

Tablo 1'te bibliyometrik analiz için WoS Core Collection veri tabanından araştırma alanı üzerine yayınların bibliyografik verilerinden oluşan veri setine dair temel bilgiler bulunmaktadır. 2019-2021 yılları arasında veri setinde incelenen doküman sayısı 66, kaynak sayısı 136; bunların içinde 120 dergi makalesi, 14 editoryal, 1 bildiri ve 1 kitap incelemesi bulunmaktadır. Veri setindeki 136 kaynağın içinde 85 anahtar kelimeye sahiptir. 136 kaynakta 4425 atıf yapılmıştır. 136 kaynak toplam 244 yazar tarafından yazılmıştır. Tek yazarlı yayın sayısı 79'dur. Yazarlar arasında işbirliği endeksi 2.81'dir. Ortak yazarlık/araştırma endeksi olarak görülebilecek bu endeks sayısı, çok yazarlı eserlerdeki toplam yazar sayısının çok yazarlı eserlerin sayısına bölünmesiyle elde edilir.

Tablo 1. Bibliyometrik Analizde Kullanılan Veri Setine Dair Temel Bilgiler

\begin{tabular}{ll}
\hline Veri Seti Tanımlama & Sonuç \\
\hline Yıllar & $2019-2021$ \\
\hline Doküman Sayısı & 66 \\
\hline Kaynak Sayısı & 136 \\
\hline WoS Anahtar Kelime Sayısı & 85 \\
\hline Alınt Sayısı & 4425 \\
\hline Makale Sayısı & 120 \\
\hline Editoryal & 14 \\
\hline Bildiri & 1 \\
\hline Kitap incelemesi & 1 \\
\hline Yazar Sayısı & 244 \\
\hline Tek Yazarlı Yayın Sayısı & 79 \\
\hline İşbirliği Endeksi & 2.81 \\
\hline
\end{tabular}

Siyasi rejimler ve Covid-19 pandemisi ile ilgili en çok yayın yapan dergi, 20 makale ile interdisipliner çalışmalara odaklanan Democratic Theory: An Interdisciplinary Journal Dergisi olmuştur. Bu dergiyi 7 makale ile The Asia-Pacific Journal-Japan Focus Dergisi izlemiştir. Perspectives on Politics Dergisi 5 makale yayınlamıştır. 18 atıfla, en fazla atıf almış olan erken yayında bir makale, pandemi süresinde karantina öncesi ve sonrası 15 Batı Avrupa ülkesinde yapılan bir anket çalışmasına dayanmaktadır. European Journal for Political Research adlı dergide yayımlanan bu makale, pandemi süresinde hükümet partilerine ve liderlere siyasi desteğin arttı̆ını, ama bu desteğin arkasında ideolojik bir 
etkinin bulunmadığın bulgulamıştır (Bol vd., 2020). En fazla atıf alan ikinci yayın, 14 atıfla Democratization adlı dergide yayınlanmış, Demokrasinin Çeşitleri Projesi'nin (V-Dem) dünyada otokratikleşme dalgasının hızlandığı ve protestoların yayıldığ 2019 yılına dair verilerini aktaran makaledir. 11 atıfla en fazla atıf alan üçüncü yayın, Güney Kore örneğiyle, Covid-19 pandemisi bağlamında akıllı şehir politikalarını inceleyerek gözetleme teknolojilerinin demokratik kontrolünü nasıl mümkün hale getirebileceğini tartışmaktadır. Makale Eurasian Geography and Economics adlı dergide yayımlanmıştır (Sonn ve Lee, 2020).

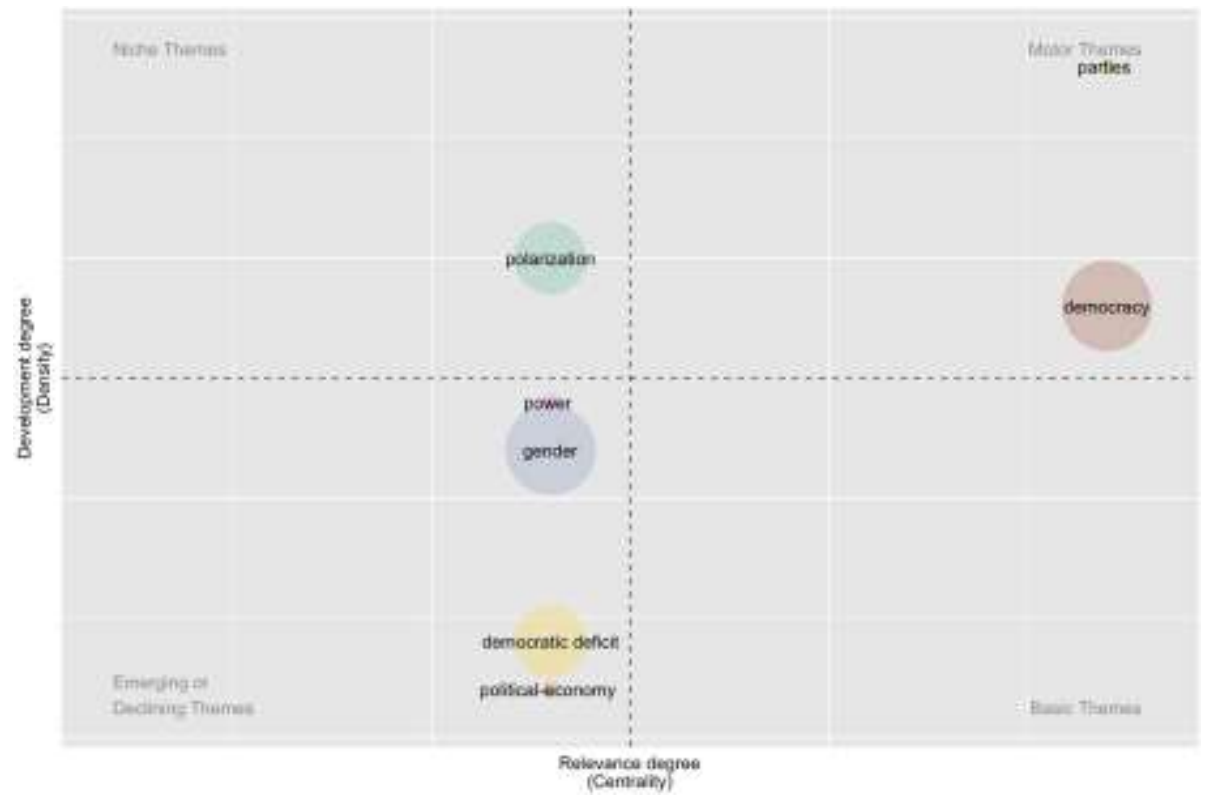

Şekil 1. Araştırma Alanının Kavramsal Haritası

Şekil 1'deki kavram haritasında, sağ üst çeyrekte, demokrasi (democracy) motor kavramdır. Şekilde görünmemekle birlikte, demokrasi kümesinin içinde kamu politikası (policy) da yer almaktadır. Araştırma alanında odak noktası demokrasi kavramıdır. Sorgu komutuyla veri setine dahil edilecek eserleri belirlerken "siyasi rejimler", "otoriteryanizm" gibi farklı anahtar kelimelerin de kullanıldığı göz önünde bulundurulursa, demokrasi kelimesiyle kamu politikasının motor kavramlar olarak ön plana çıkması ilgi çekicidir. Siyasi partiler (parties) kavramı tek başına bir küme olarak yoğunluk düzeyi 
son derece yüksek bir motor kavram olmakla birlikte, bu konunun veri setindeki sıklı̆ğ (balonun çapı) düşüktür. Siyasi partiler yerine demokrasiyle kamu politikası kavramlarının birlikte en sık kullanılan kavramlar olması dikkat çekicidir.

Sol alt çeyrekte, araştırma gündeminde toplumsal cinsiyet (gender) kümesi bu alanda yeni ortaya çıan ya da önemini yitirmekte olan bir kavramı temsil etmektedir. Toplumsal cinsiyet ve etki (impact) kelimeleri aynı kümededir. Bu konuların işlendiği makalelerin bazılarının Politics and Gender alan dergisinde yayımlandığı dikkati çekmektedir. Toplumsal cinsiyet ve etki konuları farklı perspektiflerden irdelenmiştir. Virüsle mücadelede cinsiyetin ve cinsiyetçi yaklaşımın etkisi, kadınların bu süreçte karar alma mekanizmalarındaki yeri, pandemi sürecinde cinsiyet eşitsizliğinin önlenmesinde koruyucu kurumların rolü ele alınmıştır (Druckman ve Sharrow, 2020; Reny, 2020; Smith, 2020). Şekil 2' de Sankey Diyagramı'nda görüldüğü gibi bu alanda en fazla esere sahip olan ABD adresli akademisyenler toplumsal cinsiyet kavrammı ön plana çıkarmıştır. Demokratik açık (democratic deficit), yeni ortaya çıkan ya da önemini yitirmekte olan başka bir konu kümesidir ve bu küme içinde Avrupa Birliği (European Union, EU) kavramının olduğu görülmektedir. Sol alt çeyrekteki güç (power) ve siyasi ekonomi (political economy) kavramlarının veri setinde sıklığı epey düşüktür. Güç ile toplumsal cinsiyet kavramları birbirlerine yakın ölçüde merkezi ve yoğunluk değerlerine sahiptir. İkisi de ortaya yakın düzeyde kendi içinde gelişmiştir ve başka kümelerle bağlantılıdır. Demokratik açık ve siyasi ekonomi birbirlerine yakın ölçüde merkezi ve yoğunluk değerlerine sahiptir. İkisi de kendi içinde oldukça az gelişmiş olmakla birlikte başka kümelerle bağlantılıdır.

Gelişmiş ama kendine has konuların olduğu sol üst çeyrekte, kutuplaşma kümesinin içinde devlet (state) bulunmaktadır. Kutuplaşma, kendi içinde oldukça gelişmiş, araştırma alanındaki başka konularla bağlantılı bir konudur. Sankey Diyagramı kutuplaşma anahtar kelimesini veri setinde en fazla esere sahip olan ABD adresli akademisyenlerin ABD üzerine inceleme yaparken kullandığını ortaya koymuştur. Ancak veri setinde yer alan dört makaleden üçü ABD üzerinedir. Bir makalede Macaristan örneğinde liberal olmayan (illiberal) rejimlerde siyasi liderlerin ulusal kriz durumunda birlik sağlamak yerine kutuplaşmayı artırmayı tercih ettikleri öne sürülmüştür (Kadar, 2020). 
İlginç başka bir husus, sol çeyrekteki tüm konuların merkezilik düzeyinin birbirine yakın olması ve sağ çeyreklere yakın olmalarıdır. Dolayısıyla, araştırma alanında bu kavramların zamanla merkezilik ve yoğunluklarının değişmesi durumunda kavramsal haritadaki rollerinin de farklılaşma ihtimali vardır. Özetleyecek olursak, araştırma alanında demokrasi ve kamu politikası önemli, yön verici ve gelişmiş konulardır. Toplumsal cinsiyet, güç, demokratik açık ve siyasi ekonomi yeni ortaya çıan ya da önemini yitirmekte olan konulardır. Kutuplaşma kendi içinde gelişmiş ve diğer konularla bağlantılı bir kümedir. Diğer konularla etkileşim düzeyi sol alt çeyrekteki konularınkine yakın düzeydedir.

Şekil 2'de soldan sağa doğru WoS anahtar kelimeleri (Keyword Plus), yayın adreslerindeki ülkeler ve eser başlıklarından oluşan üç analiz biriminin birbiriyle bağlantısı Sankey Diyagramı'yla gösterilmiştir. Veri setinde en sık rastlanan ilk 10 anahtar kelime ve ilk 12 ülke ve başlık parametreleri üzerinden içerme endeksi görselleştirilmiştir. Sütunların uzunluğu veri seti içinde analiz biriminde yer alan kelime sayısı ile orantılıdır. Sol sütunda WoS anahtar kelimelerinde yukarıdan aşağıya doğru toplumsal cinsiyet, kutuplaşma, siyasi ekonomi, etki, kamu politikası, demokrasi, AB, demokratik açık, siyasi partiler ve güç kelimeleri yer alır. Orta sütundaki ülkeler sırasıyla $A B D$, Birleşik Krallık, Avustralya, Japonya, Almanya, Çekya, Kanada, Ukrayna, İtalya, Avusturya, Rusya ve İspanya'dır. Sağ sütundaki eser başlıklarında en sık geçen kelimeler yukarıdan aşağıya sırayla Covid, pandemi (pandemic), kriz (crisis), demokrasi, Güney (South), otoriteryan (authoritarian), vaka (case), yanit (response), zaman (time), küresel (global), devlet, Avrupa (European) kelimeleridir. Sütunlar arası bağlantıyı gösteren kanalların kalınlığı analiz birimleri arasında paylaşılan ortak kelime sayısıyla orantılıdır. ABD adresli yayınlar, toplumsal cinsiyet, kutuplaşma, siyasi ekonomi ve demokrasi anahtar kelimelerini sıklıkla kullanmışlardır; tüm başlıkların neredeyse hepsini kullanmışlardır. En sık kullanılan anahtar kelimeler Kanada adresli yayınlarda güç; Almanya adresli yayınlarda demokratik açık ve siyasi ekonomi; Avusturalya adresli yayınlarda siyasi ekonomi; Japonya adresli yayınlarda Avrupa Birliği ve demokratik açı; Çekya adresli yayınlarda siyasi partiler, demokrasi ve AB; Ukrayna adresli yayınlarda siyasi partiler; Birleşik Krallık adresli yayınlarda siyasi ekonomi, etki, kamu politikasıdır. İtalya, Avusturya, Rusya ve İspanya adresli yayınlar anahtar kelimelerle değil, başlıklarla eşleştirilmiştir. 
Şekil 2'de Sankey Diyagramı ile kavramsal harita karşılaştırıldığında, toplumsal cinsiyet ve kutuplaşmanın belirgin bir ağırlı̆̆ının olduğu, bu kelimelerle birlikte siyasi ekonomi ile demokrasinin ABD adresli yayınlarda anahtar rol taşıdığı görülmüştür. Kanada adresli ilgili yayınlar bu araştırma alanında yayın sayısı bakımından ikincidir. Bu yayınlarda güç kavramının odak noktası olduğu gözlenmiştir. Almanya, Çekya ve hatta Japonya adresli yayınlarda demokratik açık, $\mathrm{AB}$ ve siyasi ekonomi kelimeleri anahtar role sahip olmuştur. Birleşik Krallık ve Avustralya adresli yayınlarda en sık siyasi ekonomi, kamu politikası ve etki anahtar kelimeleri kullanılmıştır.

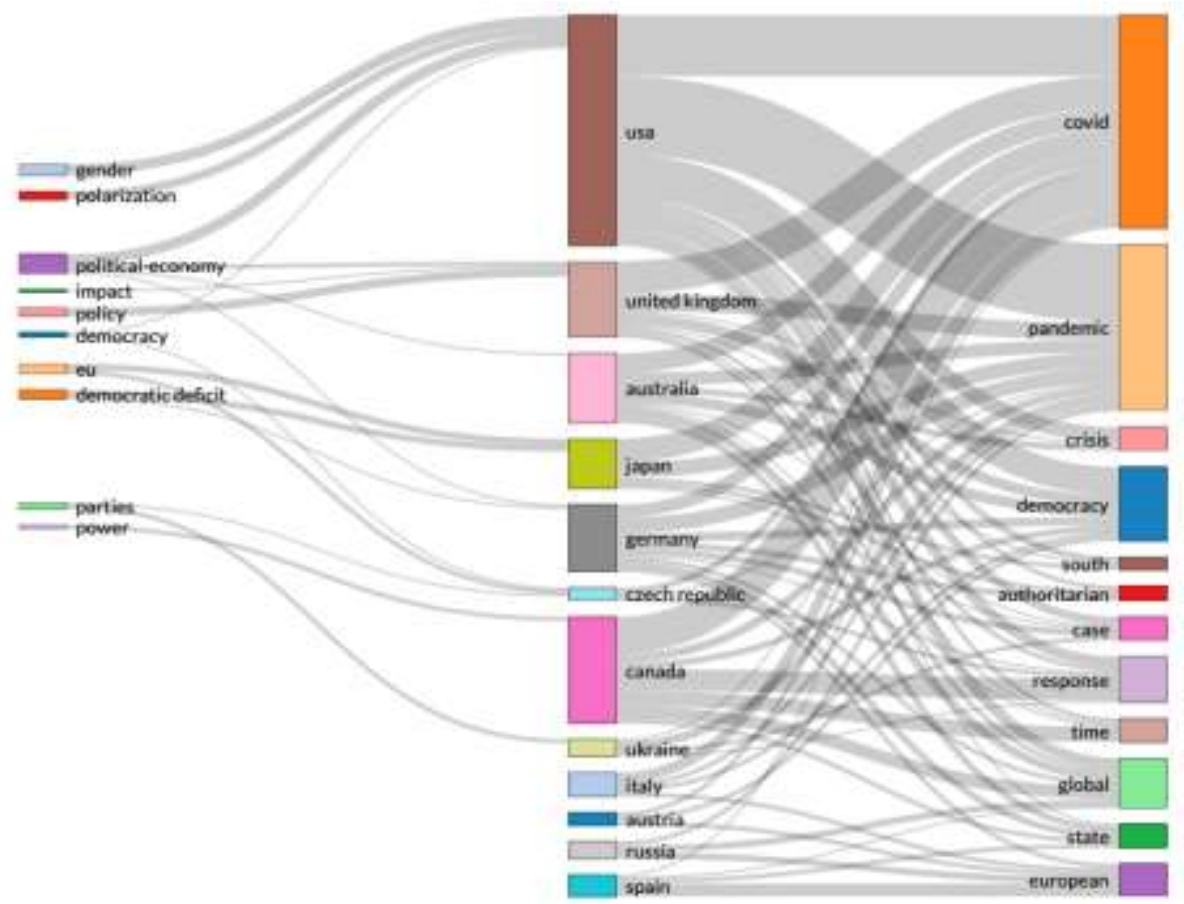

Şekil 2. Sankey Diyagramıyla Bibliyometrik Analiz Sonuçları 


\section{Bayesci (Önsel)Meta-Analiz: COVID-19 Pandemisi ve G7 Örneğinde Liberal Demokrasiler}

Çağdaş demokrasi çalışmalarının öncülerinden Robert Dahl (1971) demokrasi kavramının içerdiği değerler itibariyle bir ideal siyasi sisteme karşlık geldiğinden, "poliyarşi" kavramının ülkelerin demokratik bir devlet yönetimine sahip olup olmadığı ve ne ölçüde demokratik olduğunu araştırmada daha yararlı olacağını öne sürmüştür. Demokrasiye en yakın olan siyasal sistemi "poliyarşi" çoklu yönetimler, yani iktidarın çoğulculuk prensibine göre çeşitlendiği rejimlerdir. Dahl (1993) “Demokrasi ve Eleştirileri” başlıklı eserinde poliyarşinin yedi kuruma dayandığını belirtir: oy kullanma hakkı, seçilme özgürlüğü, adil ve özgür seçimler, seçimle başa gelenlerin yürütme erkine sahip olması, yurttaşların ifade özgürlüğü, alternatif bilgi edinme kaynakları, örgütlenme özgürlüğü.

Siyasi rejimleri bir sürekli ölçekte düşünürsek, kapalı otokrasiden veya totaliter rejimlerden seçimli otoriteryanizme, kusurlu demokrasilerden liberal demokrasiye doğru bir sıralama yapılabilir. Kusurlu demokrasilerde özgür ve adil seçimler halen geçerlidir. Schedler (2007) "seçimli otoriteryanizm" kavramı ile hükümetin siyasi baskı, sansür uygulaması ve korku yayması nedeniyle seçimlerin anlamını yitirdiği, seçimlerin otoriter rejimleri meşrulaştırmaya yaradığı yönetim biçimlerini tarif etmektedir. Kusurlu demokrasilerden farkı seçim öncesi oyun kurallarının manipüle edilmesi ve seçimlerin ne özgür ne de adil olmasıdır. Kapalı otokrasilerde seçimlerin anlamsızlı̆̆ının yanında yürütmenin hak ve özgürlüklerin ihlali de yüksek düzeydedir. Liberal demokrasiler siyasi haklar ve sivil özgürlüklerin garanti altına alındığı, hukukun üstünlüğüne riayet edildiği ve kuvvetler ayrılığının mevcut olduğu, yürütme erkinin yargı ve yasama tarafından sınırlandığı siyasi rejimlerdir.

Çalışmamızda G7 ülkelerinde pandemi ve liberal demokrasi etkileşimini araştırmak için Freedom House Endeksi kullanılmıştır. Freedom House Endeksi siyasi haklar ve sivil özgürlüklerin seviyesini ölçen bir endekstir. Üçüncü bölümde kullanılan V-Dem Projesi' nin geliştirdiği Pandemiden Dolayı Demokraside Gerileme Projesi (Pandemic Backsliding Project (PanDem)) de yine hak ve özgürlüklerin seviyesini ölçer. Freedom House hem her ülkeyi değerlerine göre sıralar hem de her ülke için arka planı aktaran betimleyici metinler yayınlar. Siyasi hakların boyutları seçim süreci, siyasi çoğulculuk ve 
katılım ile devletin işleyişidir. Sivil özgürlüklerin boyutları ifade ve inanç özgürlüğü, toplanma ve örgütlenme hakları, hukukun üstünlüğü ile kişisel özerklik ve bireysel haklardır. Siyasi haklar için en fazla 40, sivil özgürlükler için en fazla 60 puan alınabilir. Tüm puanların toplamına göre ülkeler üç kategoride sınıflandırmıştır: özgür, kısmen özgür, özgür değil (Freedom House, 2021b). Tablo 2' de görüldügü gibi tüm G7 ülkeleri üst skalada özgür ülkelerdir.

\section{Yöntem}

Meta-analiz, bir konu üzerinde daha önce yapılmış çalışmaların bir örüntü ile derleyen istatistiksel bir yöntemdir. Genel olarak güncel literatür klasik meta analiz ile değerlendirme eğilimindedir. Bayesci yaklaşım ise önsel olasılıkları göz önünde bulundurduğundan çalışmamızda kullanılmıştır. Frekanscı meta analizde sabit ve rastgele etki modeli şeklinde temel iki model bulunmaktadır. Bayesci yaklaşım ise bu iki etki modeli yerine önsel olasılıkları dikkate alır. Bu nedenle bilgilendirici (informative) ve bilgilendirici olmayan (noninformative) önsel durumların olduğu çalışmaların sonsal dağılımlarının tahmin edilmesi ile parametre tahmini yapılmaktadır. Bu kapsamda çalışmada endeks değerlerinin etki güçleri belirlenmek istenmiş ve önsel bilginin örüntü düzeyi anlamlandırılmaya çalışılmıştır.

Freedom House "Dünyada Özgürlük" (Freedom in the World) başliğı altında yıllık raporlar yayımlamaktadır. Çalışma materyalini, yani incelenen grupları 9 Şubat 2021 tarihinde G7 ülkelerindeki Dünya Sağlık Örgütü'nün resmi kümülatif Covid-19 vaka sayısı ve vefat sayısı ile Freedom House 2020 endeks değerleri oluşturmuştur. İyileşen sayılarına dair her ülke bilgilendirme yapmadığ için bu sayılar çalışmamızda kullanılmamıştır. Meta-analize iki çalışmadan toplam 7 ülkeye dair veriler dahil edilmiştir. Mevcut durum ile ilgili bilgiler ise Tablo 2'de verilmiştir. 2020 endeks değerleri ve Covid-19 vaka sayılarının meta-analizi bilgisayar yazılımı JASP (Sürüm 0.14.1), "JASP" Ekibi (2020) ile gerçekleştirilmiştir. Rastgele etkiler modeli, heterojenlik değerlendirilerek seçilmiştir. Prevalans, düşük güven aralığı (LCI)\%95, yüksek güven aralığı (HCI)\%95'tir. Ağırlık yüzde olarak (\%) belirtilmiştir. 
Tablo 2. G7 ülkelerinin Dünya Sağlı Örgütü Covid-19 Verileri ile Freedom House 2020 Endeks Değerleri

\begin{tabular}{lllll}
\hline Ülke & Vaka sayısı & İyileşen & Vefat sayısı & Freedom House Endeksi (2020) \\
\hline Kanada & 808000 & 747000 & 20835 & 98 \\
\hline Fransa & 3340000 & & 79423 & 90 \\
\hline Almanya & 2300000 & & 62191 & 94 \\
\hline İtalya & 2640000 & 365000 & 6507 & 89 \\
\hline Japonya & 407000 & & 113000 & 94 \\
\hline Birleşik Krallık & 3900000 & & 465000 & 86 \\
\hline ABD & 27100000 & & 91580 & 96 \\
\hline
\end{tabular}

Freedom House Endeksi (Freedom House, 2021a) ve Dünya Sağlık Örgütü (WHO, 2021)

Egger'in doğrusal regresyon testi meta-analizdeki çalışmaların etki büyüklüklerini ve standart hataların doğrusallığını test etmek için kullanılmıştır. Ülke önyargısını ortadan kaldırmak için Duval ve Tweedie'nin kırpma ve doldurma yöntemi uygulanmış ve ortak maruziyet değeri yeniden hesaplanmıştır (Duval ve Tweedie, 2000). Grup içi varyansa ek olarak gruplar arasındaki varyansı belirlemek amaciyla rastgele etkiler modeli (DerSimonian-Laird yöntemi) kullanılmıştır (DerSimonian ve Laird, 2015). (K-1) serbestlik derecelerine yönelik çalışmalardaki etki büyüklüklerinin heterojenliğinin değerlendirilmesinde Cochrane'in Q istatistikleri, heterojenlik düzeyini belirlemek için $\mathrm{I}^{2}$ istatistiği ve çalışmalar arasındaki gerçek varyansı belirlemek için $\tau^{2}$ istatistiği kullanılmıştır. $\mathrm{I}^{2}$ değeri, Patsopoulos ve arkadaşları tarafından önerildiği üzere üç kategoride değerlendirilmiştir. \%25'in altı düşük, \%25-50 orta ve \%50'nin üstü yüksek heterojenliktir (Patsopoulos vd., 2008).

\section{Bulgular}

Tablo 3'te meta-analize dahil edilen sonuçların çalışma etki büyüklüklerinin ve standart hataların doğrusal olup olmadığını belirlemek için Egger' in Doğrusal Regresyon testi kullanılmıştır. Yayın yanlılığının giderilmesi için Duval ve Tweedie'nin (2000) kırpma ve doldurma yöntemi uygulanarak ortak maruziyet değeri tekrar hesaplanmıştır. Grup içi varyansın yanı sıra gruplar arasindaki varyansı tespit etmek amaciyla rastgele etki modeli (DerSimonianLaird yöntemi) kullanılmıştır (Sutton vd., 2001). Çalışmaların etki büyüklüklerine ait heterojenliğin değerlendirilmesinde (k-1) serbestlik dereceli Cochrane's $Q$ istatistiği, heterojenlik seviyesini belirlemek için $I^{2}$ istatistiği ve çalışmalar arasındaki gerçek varyansın tespiti için $\tau^{2}$ istatistiği kullanılmıştır. 
Yanlılık için değerlendirildiğinde, yanlılığa dair özet istatistiklere bakıldığında $I^{2}$ değeri \%37,05 olarak belirlenmiştir. Çalışmamızda orta düzeyde bir yanlılık vardır (Şekil 3).

Tablo 3. Yanhlı̆̆a Dair Özet İstatistikler

\begin{tabular}{|c|c|c|c|c|c|c|c|c|c|c|c|}
\hline \multicolumn{2}{|c|}{$\begin{array}{l}\text { Fail-Safe N } \\
\text { Analysis (File } \\
\text { Drawer Analysis) }\end{array}$} & $\begin{array}{l}\text { Rank Correla- } \\
\text { tion Test for } \\
\text { Funnel Plot } \\
\text { Asymmetry }\end{array}$ & \multicolumn{4}{|c|}{$\begin{array}{l}\text { Regression Test for } \\
\text { Funnel Plot Asymmetry }\end{array}$} & \multicolumn{4}{|c|}{ Heterogeneity Statistics } & \multirow[b]{2}{*}{$\mathrm{p}$} \\
\hline $\begin{array}{l}\text { Fail-safe } \\
\text { N }\end{array}$ & $\mathrm{p}$ & $\begin{array}{l}\text { Ken- } \quad p \\
\text { dall's } \\
\text { Tau }\end{array}$ & $\mathrm{Z}$ & $\mathrm{p}$ & Tau & Tau $^{2}$ & $I^{2}$ & $\mathrm{H}^{2}$ & df & $\mathbf{Q}$ & \\
\hline 29258.000 & $<.001$ & $\begin{array}{l}- \\
0.999\end{array}$ & $\begin{array}{l} \\
4.205\end{array}$ & $<.001$ & 0.733 & $\begin{array}{l}0.537 \\
(\mathrm{SE}= \\
0.0425)\end{array}$ & $37.05 \%$ & 3.035 & 6 & 18.228 & .006 \\
\hline
\end{tabular}

Note. Fail-safe N Calculation Using the Rosenberg Approach

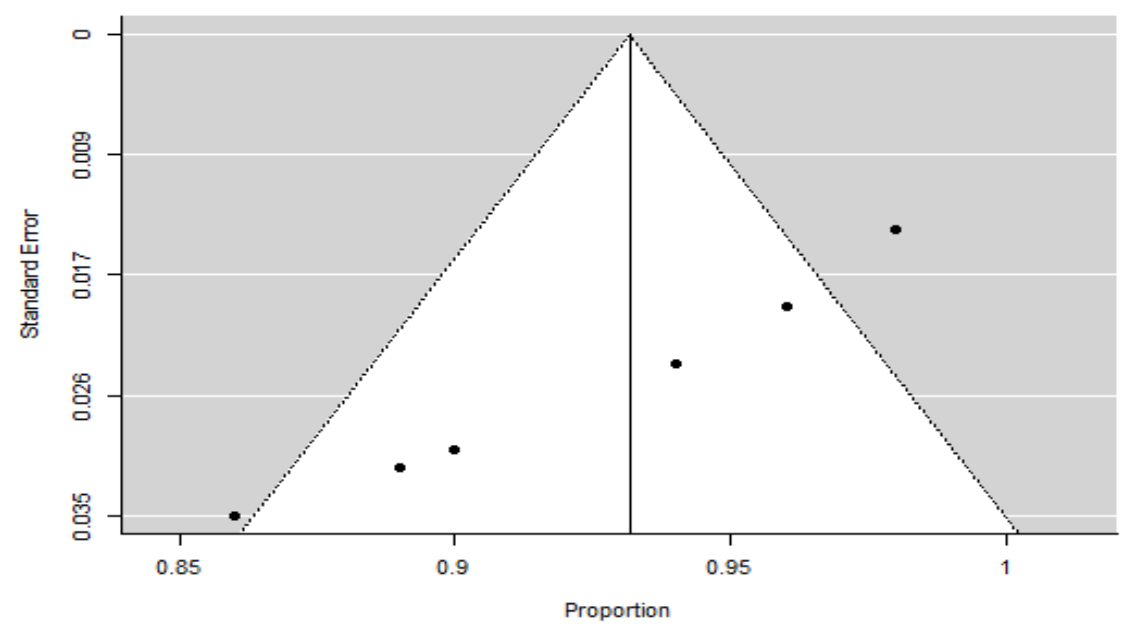

Şekil 3. Etki Gücüne Ait Huni Grafiği (Funnel Plot)

Önsel dağılımlar kendi içerisinde "bilgilendirici" ve "bilgilendirici olmayan" olarak ifade edilir. Her iki yaklaşım arasında ağırlıklandırma konusu temel farklılığı oluşturmaktadır. Bilgilendirici olmayan önsel dağılımda örneklem bilgisi ağırlıklandırma için oldukça önemli bir rol oynamaktadır. Ancak 
bilgi verici önsel dağılımda bu durum sonsal dağılım için kısmı olarak ağırlıklandırma yapmaktadır (Bolstad ve Curran, 2016). Beta dağılımında bu parametrelerin $(a, b)$ değeri farklılaştıkça önsel dağılımlar (informative, non-informative) meydana gelmektedir. Eğer $(a, b)$ parametrelerine 1 değerini alırsa (uniform $(0,1)$ dağılımı oluşmaktadır) $\theta$ parametresinin rastgele seçilen bir parametresi eşit uzaklıkta değer alabileceği için bilgilendirici olmayan önsel dağılım meydana gelmektedir. Eğer $(a, b)$ değeri 0.5 değeri alırsa $\theta$ parametresi sınır değerlere yaklaşacağından merkezdeki değerlerin seçim olasilığ1 daha az olacak ve kısmi bilgilendirici olmayan önsel dağılım meydana gelecektir. Eğer $(a, b)$ değeri 0.5-1 aralığında bir değer alırsa, $\theta$ parametresi bilgi verme açısından en güçlü kestirimine gelecektir. Böylece $\theta$ parametresi bilgilendirici olarak ifade edilebilecektir.

Araştırma sonucuna göre Bayesci yaklaşıma sahip meta-analizin frekansçı yaklaşıma sahip meta analizden daha güçlü tahmin değeri olduğu belirlenmiştir. Bu sebeple, Bayesci yaklaşımın avantajı bulanık varyasyon kaynaklarından frekansçı meta analiz yaklaşımına göre daha net bilgi elde edebilmektir. Sonuç olarak, Bayesci meta analizinin hesaplama adımları ve süreçleri yapılan simülasyon sonuçlarına göre daha kolay hale gelmiştir.

Tablo 4. Tau ${ }^{2}$ Kestricisi Bayes Rastgele Etkileri Modeli

\begin{tabular}{lllllll}
\hline \multicolumn{2}{l}{ Random-Effects Model $(\mathbf{k}=\mathbf{7})$} & & & & \\
\hline & Estimate & se & $\mathrm{Z}$ & $\mathbf{p}$ & $\begin{array}{l}\text { CI Lower } \\
\text { Bound }\end{array}$ & $\begin{array}{l}\text { CI Upper } \\
\text { Bound }\end{array}$ \\
\hline Intercept & 0.932 & 0.0156 & 59.7 & $<.001$ & 0.901 & 0.962 \\
\hline
\end{tabular}

Çalışmada etki büyüklüğü (estimate) $0.932(0.901-0.962)$ p <0.01 olarak belirlenmiştir (Tablo 4). Belirlediğimiz ülkeler için yapılan değerlendirme endeksinin ya da uygulanan yöntemlerin anlamlı bir etkisinin olduğunu öne sürebiliriz. İlgi kriterleri ile model uyumuna bakıldığında modelin orta düzeyde uyumlu ve sonraki çalışmalar için yol gösterici olabileceği öngörülmektedir. Varyasyonu açıklamak için; Tablo 5'te modele uyum istatistikleri ve bilgi kriterleri olan log olabilirlik (log-likelihood), Akaike bilgi ölçütü (Akaike Information Criteria, AIC), Bayes bilgi ölçütü (Bayesian Information Criteria, $B I C)$, düzeltilmiş Akaike bilgi ölçütü (AIC Corrected, AICC) ve olabilirlik oran testinden (Likelihood Ratio Test, LRT) faydalanılmıştır. AIC, log-olabilirlik ve parametre sayısını (Akaike, 1974), BIC ise log-olabilirlik ve parametre sayısı ile birlikte örneklem büyüklüğünü kullanmaktadır (Schwarz, 1978). AIC, BIC ve AICC (Hurvich ve Tsai, 1989) istatistikleri şu eşitlikte verildiği gibidir: 


$$
\mathrm{AIC}=-2 l l+2 p ; B I C=2 l l+p \ln (n) ; A I C C=A I C+\frac{2 p(p+1)}{n-p-1}
$$

Tablo 5. Modele Uyum İstatistikleri ve Bilgi Kriterleri

\begin{tabular}{llllll} 
& $\begin{array}{l}\text { log-likeli- } \\
\text { hood }\end{array}$ & Deviance & AIC & BIC & AICc \\
\hline $\begin{array}{l}\text { Maximum-Li- } \\
\text { kelihood }\end{array}$ & 12.787 & 13.588 & -21.574 & -21.682 & -18.574 \\
\hline $\begin{array}{l}\text { Restricted } \\
\begin{array}{l}\text { Maximum-Li- } \\
\text { kelihood }\end{array}\end{array}$ & 10.519 & -21.039 & -17.039 & -17.455 & -13.039 \\
\hline
\end{tabular}

Şekil 4'te orman grafiğinde görüldügü gibi, ülkelere ait etki büyüklükleri, göreceli ağırlıklarına ait bulgular yer almaktadır. Bağıl ağırlık (relative weight) değerine göre Kanada ve Japonya en yüksek (yüzdesel) ağırlığa sahiptir. Orman grafiğindeki kare simgesi ülkelere ait etki büyüklüğünü karelerin boyutları ise çalışma büyüklüğünü ifade etmektedir. Dikey eksendeki ülkelere göre yatay eksendeki kare simgesinin çizgileri etki büyüklüğünün \%95 olasılıkla güven sınırlarıdır. Yatay eksendeki elmas şekli ise genel etki büyüklügünü ifade etmektedir. Genel etki büyüklüğü 0,93 olarak bulunmuştur. Ülkelere karşılık gelen kare şeklinin genel etkiye karşıllık gelen elmas şekline olan uzak/yakın konumuna ilişkin özet bilgiyi belirtmektedir. İtalya ve ABD Freedom House 2020 endeks değerleri ve Covid-19 vaka sayıları arasında güçlü bir pozitif ilişki bulunmaktadır. Freedom House endeks değerinin düşük olması nedeniyle vaka sayılarındaki artısın pozitif yönde olması analiz sonucunda önsel olarak beklenen bir durum haline gelmiştir. 


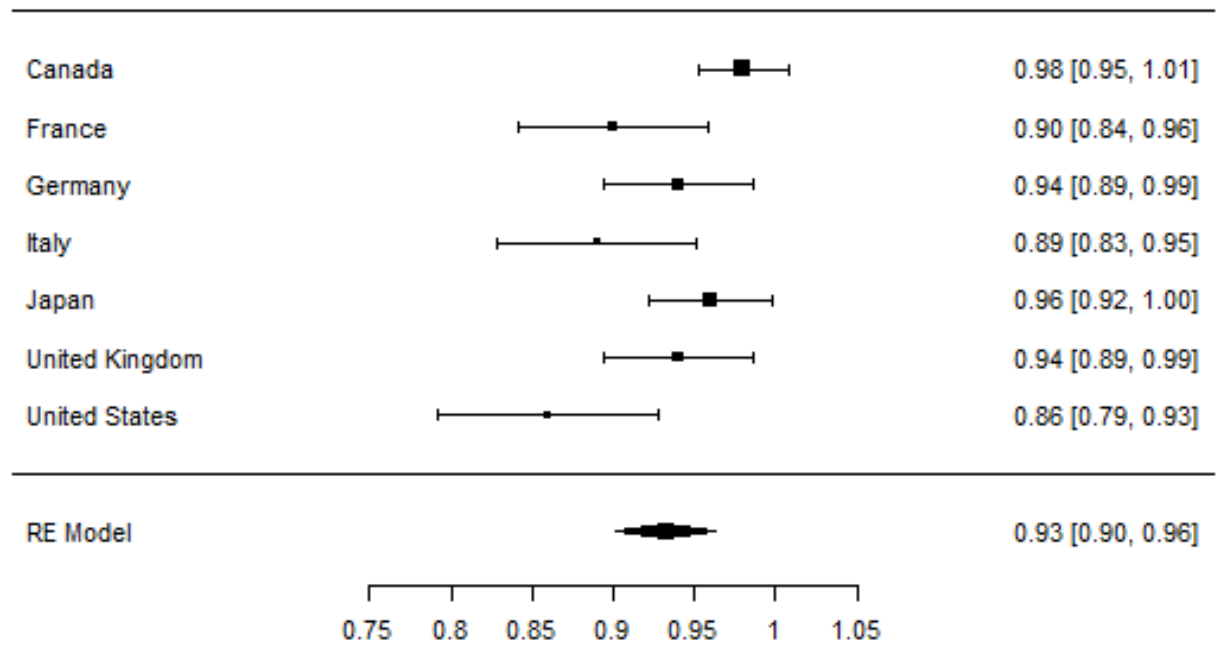

Şekil 4. Freedom House Endeksi 2020 Değerlerinin G7 Ülkelerine Ait Orman Grafiği (Forest Plot)

Şekil 5 Freedom House 2020 Endeks değerleri ve Covid-19 vaka ve vefat sayıları arasındaki korelasyon örgüsü incelendiğinde Freedom House Endeksi endeks değeri arttıkça toplam vaka sayılarında azalma olması öngörülmektedir. Ayrıca toplam vaka sayıları arttıkça vefat sayılarının da artacağı öngörülmüştür. Freedom House Endeksi endeks değeri arttıkça toplam vaka sayılarında \%72,9'luk azalma, toplam vefat sayılarında ise \%77,3'lük bir azalma olması istatistik olarak tahmin edilmiştir. Ayrıca, doğal olarak toplam vaka sayıları arttıkça \%99,3 oranında vefat sayılarının da artacağı öngörülmüştür. 


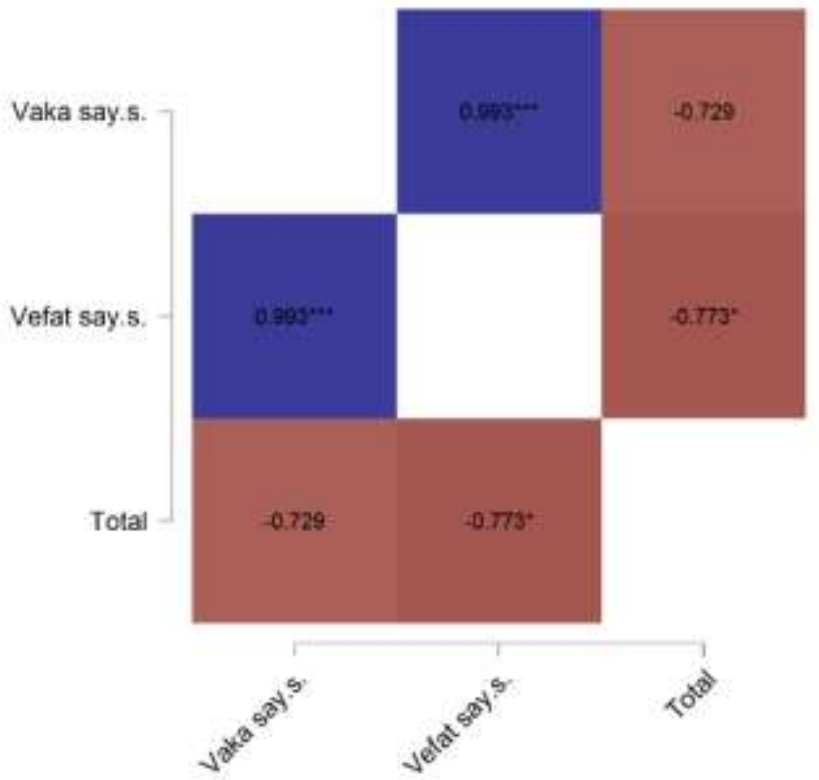

Şekil 5. Freedom House 2020 Endeks Değerleri ve Covid-19 Vaka ve Vefat Sayıları Arasındaki Korelasyon Örgüsï

Bayesci (önsel) meta-analiz sonuçlarının nedensel ilişki kurmadığının altı çizilmelidir. Sahte ilişkiyi yansıtma ihtimali göz önünde bulundurulmalıdır. Bayesci hipotez kontrollerinin en hassas noktası Bayes faktörüdür. Belirtilen hipotezin ne kadar güçlü kanıt değeri sunduğunun p değerine karşı ifadesi olarak nitelendirilebilir. Sonsal olasılıkları hesaplayabilmek için mevcut hipotezlere ait önsel olasılıkların zamana bağlı değişim ve gelişimleri göz önünde bulundurulur. Fakat Bayes faktörü sıfır ve karşıt hipotezlere ilişkin önsel kanıt değerlerine göre sıklığın ifade eder. Bu yüzden, meta-analizlerin gelecekteki zaman kesitlerinde de gerçekleştirilmesi faydalı olacaktır. Bayesci çalışmalar zamana bağlı şekilde tekrarlandığında kümülatif bilgi üretecek, kıyaslanabilir önsel ve sonsal bilgi kümesi oluşturacaktır. Ayrıca G7 ülkesi dışındaki liberal demokrasiler analize dahil edilebilir. Toplam demokrasi verileri ile bir çıkarımda bulunmak yeterli olmayabilir. G7 ülkelerinin Freedom House Endeksi değerleri yüksek olduğundan, farklar bariz değildir. Ülkeler arasindaki siyasi hak ve sivil özgürlüklerin boyutlarına inilerek Bayesci önsel meta-analiz gerçekleştirilebilir. Endeksler göz önünde bulundurulduğunda liberal demokrasi değerleri yüksek ülkelerde demokrasinin işleyişinde sorun 
olmadığı varsayımı yapılabilir. Fakat, siyasi hak ve sivil özgürlüklerin boyutlarına indiğimizde, siyasi katılım düzeylerinde azalma, özellikle sosyal dışlanmışlı̆̆ın ve temsili demokrasi kurumlarına güvensizliğin sonucu olarak siyasi katılım oranında azalma tespit edilmiştir (Krause ve Merkel, 2018).

Bu kisitlar not edildikten sonra belirtmek gerekir ki, ilgi kriterleri ile model uyumuna bakıldığında model orta düzeyde uyumludur ve sonraki çalışmalar için temel oluşturabileceği öngörüsüne ulaşılmıştır. Covid-19 pandemisiyle mücadelenin yaşama hakkı gibi en önemli insan hakkını korumak anlamına geldiği bir süreçte ekonomik gelişme düzeyi ve demokrasi değerleri üst seviyede olan ABD ve İtalya göreceli olarak başarısız kalmıştır. G7 ülkelerinden İtalya ve ABD'nin göreceli olarak başarısız kalmasını, Almanya, Danimarka, Tayvan, Güney Kore gibi ülkelerin vaka sayısını kontroldeki başarısını sosyal demokratik kapitalizme ve kalkınmacı devlete bağlayan çalışmalar vardır (Pepinsky, 2020). Hangi siyasi rejimlerin pandemi önlemlerini daha verimli uyguladığına yönelik 111 ülke karşılaştırması incelendiğinde, demokrasilerin coğrafi hareketliliği (mobility) kıstlamada otokrasilerden daha başarılı olduğuna, kolektivist kültürel değerlerin hakim olduğu ülkelerin bireysel değerlerin hakim olduğu ülkelere göre daha başarılı olduğuna dair bulgular elde edilmiştir (Benedikt Frey vd., 2020).

\section{Liberal Demokrasilerin Pandemi Sınavı ve Endeks Değerleriyle Bibliyometrik Analiz Sonuçlarının Karşılaştırılması}

Lipset hipotezi sağlamlığını kanıtlamış olsa da ekonomik gelişmişlik düzeyi yüksek ülkelerde liberal demokrasinin krizde olduğuna dair tartışmalar 1970'lerden bu yana temel sorular eşliğinde gündeme gelmiştir: "günümüzdeki haliyle siyasi demokrasi uygun bir yönetim biçimi midir?" (Crozier vd., 1975 , s. 2) Chantal Mouffe, liberalizm ve demokrasi arasındaki bağın birbirini gerektirmediğini, bağın tarihsel mücadeleler sonucunda oluştuğunu belirtir. Mouffe'a göre, liberal gelenekte hukukun üstünlüğü, insan hakları ve bireysel özgürlüklere vurgu ile demokratik gelenekteki yönetilenle yöneten arasındaki eşitlik prensibinin Avrupa ve Amerika'da birlikte olmasının nedeni demokratik kurumların tarihsel gelişimidir (Mouffe, 2000, s. 2). Colin Crouch (2004), "post-demokrasi” döneminde seçimlerin demokrasinin göstergesi ol- 
maktan uzaklaştığını, küresel sermayenin ekonomik kararları etkilemede giderek daha önemli rol oynadığını, medyanın siyaseti kişiselleştirdiği ve siyasetin içini boşalttığını öne sürer.

G7 ülkeleri örneğinde liberal demokrasiler pandemi döneminde nasıl bir sinav verdiler? V-Dem Projesi "Pandemiden Dolayı Demokraside Gerileme Projesi" çerçevesinde, 11 Mart 2020 tarihinde Dünya Sağlık Örgütü'nün Covid19 pandemisini ilan etmesinden Aralık 2020 başına kadar pandemiyle mücadelede demokrasi karnesini gösteren iki endeks geliştirmiştir. Demokratik Standartların Pandemiden Dolayı Çiğnenmesi Endeksi (The Pandemic Violations of Democratic Standards Index (PanDem)) pandemide yaşanan olağanüstü koşullardan ötürü demokratik hak ve özgürlüklerin ne ölçüde ihlal edildiğini ölçer. PanDem, demokratik standartların, spesifik olarak kişilerin dolaşım, örgütlenme ve ifade özgürlüğünün Covid-19 pandemisi nedeniyle yürürlüğe konan olağanüstü önlemler dolayısıyla ihlal edilip edilmediğini araştırır. Kişisel ve Siyasal Haklar Uluslararası Sözleşmesi (International Covenant on Civil and Political Rights, ICCPR) gibi uluslararası antlaşmalar çerçevesinde tanımlanan hak ve özgürlüklerin ihlali incelenmiştir. Pandemik Gerileme Endeksi (The Pandemic Backsliding Index (PanBack)) ise, devletin pandemiyle mücadele sırasında uyguladığı politikaların o ülkede demokrasinin kalitesine ne ölçüde etki ettiğini ölçer (V-Dem, 2021).

PanDem endeksinde hak ve özgürlüklerin ihlal edilmesinin tespiti için şu boyutlar belirlenmiştir: alınan tedbirlerde ayrımcllık yapma, mutlak hakların sınırlanması, kanunun uygulanması sırasında fiziksel şiddet uygulama, önlemlere zaman sinırlaması koymama, yasamanın yetkilerinin sınırlandırılması, resmi makamların yanlış bilgilendirme kampanyası uygulaması, basın özgürlüğünü kısıtlama. Boyutların göstergeleri ihlalin yokluğu (0), az ihlal (1), epey ihlal (2) ve ciddi ihlal (3) olmak üzere kodlanmıştır. PanDem endeksinde sıralama ölçeği, ihlallerin toplamı alındıktan sonra en yüksek toplamsal sayıya bölünmesiyle ve düşükten yükseğe doğru ( 0,1 aralığında) sıralanmasıyla oluşturmuştur. PanBack endeksi pandemi sırasında demokrasinin gerilemesini araştırmıştır. Endeks oluşturulurken demokrasi ile otokrasi arasında yer alan gri vakalarda gerileme riskinin daha fazla olduğu varsayımı yapılmıştır. Yüksek düzeyde demokrasi değerlerine sahip ülkelerde kurumların istikrarını koruyacağı, zaten düşük düzeyde olanların daha düşük değerlere inmesinde marjın az olduğu göz önünde bulundurulmuştur. Sıralama düşükten yükseğe doğru (0,1 aralığında) yapılmıştır: ihlalin yokluğu (0), az ihlal 
$(<0.2)$, epey ihlal $(<0.35)$, ciddi ihlal $(>=0.35)$; veri yokluğu durumu endekste belirtilir. PandDem endeksinde tüm ülke değerlerinin ortalaması gerileme riski ortalamasını verir, gri alan vakalarının kırılganlığı nedeniyle ağırlık $v 2 x \_$libdem olarak belirlenir: Panback $=4 \times$ PanDem $\times$ v2x libdem $\times(1-v 2 \mathrm{x}$ libdem) (Edgell vd., 2020).

Tablo 6. G7 Ülkelerinin PanDem Endeksi, PanBack Endeksi ve Freedom House Endeksi Değerlerinin Karşılaştırılması

\begin{tabular}{|c|c|c|c|c|c|c|}
\hline & $\begin{array}{l}\text { PanDem Puanı } \\
\text { (Mart-Aralık } \\
\text { 2020) }\end{array}$ & $\begin{array}{l}\text { PanDem } \\
\text { İhlal } \\
\text { Siralama }\end{array}$ & $\begin{array}{l}\text { PanBack Puanı } \\
\text { (Mart-Aralık } \\
\text { 2020) }\end{array}$ & $\begin{array}{l}\text { PanBack } \\
\text { Siralama }\end{array}$ & $\begin{array}{l}\text { Freedom } \\
\text { House } \\
2020\end{array}$ & $\begin{array}{l}\text { Freedom } \\
\text { House } 2000 \\
\text { Kategorisi }\end{array}$ \\
\hline Almanya & 0 & $138 / 144$ & 0 & $138 / 144$ & 94 & özgür \\
\hline İtalya & 0.1 & $120 / 144$ & 0.02 & $126 / 144$ & 89 & özgür \\
\hline Fransa & 0.1 & $118 / 144$ & 0.07 & $103 / 144$ & 90 & özgür \\
\hline $\begin{array}{l}\text { Birleşik } \\
\text { Krallık }\end{array}$ & 0.15 & $111 / 144$ & 0.08 & $97 / 144$ & 94 & özgür \\
\hline ABD & 0.3 & $54 / 144$ & 0.22 & $29 / 144$ & 86 & özgür \\
\hline
\end{tabular}

Freedom House Endeksi (Freedom House, 2021a), PanDem Projesi (V-Dem, 2021)

Tablo 6’da görüldüğğ gibi, Mart-Aralık 2020 döneminde G7 ülkelerinin hepsinde Freedom House Endeksi verileri "özgür" kategorisindedir. Sonuç, günümüz liberal demokrasileri arasında ekonomik gelişmişlik düzeyi en yüksek olan ülkelerde dahi demokratik standartların güvence altında olmayabileceğini göstermiştir. Pandemi süresinde G7 ülkelerinden Kanada ve Almanya' da demokratik gerileme yaşanmazken; İtalya, Japonya, Fransa ve Birleşik Krallık'ta düşük oranda demokratik gerileme yaşanmıştır. Freedom House Endeksi'ne göre özgür kategorisinde olan ABD'de epey ihlal kaydedilmiş, hatta 0.3 puanla ciddi ihlal kategorisine az ihlal kategorisinden daha yakındır. ABD toplam 144 ülke arasında ihlaller açısından 54. sıradadır. Demokratik standartlarda 0.22 puanla gerilemeyle, 144 ülke arasinda 29. siradadır. ABD'de özellikle resmi kaynakların yanlış bilgilendirmesi, medya özgürlügünün kısıtlanması ve pandemi kaynaklı önlemlerde zaman kısıtlamasına gitmeme hususlarında demokratik standartlar çiğnenmiştir. Freedom House pandeminin ihlaller için 5 kategoride araçsallaştırıldığını belirlemiştir: seçimlerin aksaması, yasama toplantılarının sekteye uğraması, basın özgürlüğünün kısıtlanması, protestoların kısıtlanması, gözaltı veya tutuklama, polis şiddeti. ABD'de özellikle medya kısıtlaması ve polis şiddetiyle ihlal yapılmış- 
tır. Bu tespitlerde hak ihlali türü üzerinden bir değerlendirme yapılmıştır, puanlama ve sıralama yapılmamıştır (Freedom House, 2020). Pandemiden önce de, ABD'de siyasi katılım, özellikle seçimlerde oy kullananların oranında düşüş, Afro-Amerikanlara uygulanan polis şiddeti ve siyasete güvenin azalması konularında sorunlar tespit edilmiştir (Krause ve Merkel, 2018, ss. 35-37).

Bibliyometrik analizle endeks verilerini karşılaştırmak gerekirse, ABD adresli eserlerde yazarların en sık kullandığı anahtar kelimeler kutuplaşma, toplumsal cinsiyet ve siyasi ekonomi olmuştur. ABD'de pandemiye karşı geliştirilen önlemlere de cumhuriyetçi ve demokratlar arasındaki partizan kutuplaşma damgasını vurmuştur. Öyle ki, pandemiyle ilgili bilimsel verilerin sonuçları dahi kutuplaşmış grupların görüşlerinde, kitlesel tercihler üzerine pek az etkide bulunmaktadır (Rodriguez vd., 2020). Covid-19 pandemisinin küresel etkileri tüm hükümetleri olağanüstü koşullara karşı çözümler üretmeye zorlamıştır. Dünya Bankası pandeminin ekonomik sonuçları hakkında raporunda, kadınların küresel ölçekte yaşanan ekonomik küçülmeden erkeklerden daha çok etkilendiğini, eşit değerde işlerde kadınların ücret eşitsizliğine ek olarak, kadınların yoğunlukla istihdam edildiği ve karantina önlemlerinden en çok etkilenen sektörlerden turizm ve perakende satış sektörlerinde işsizlik oranlarının daha hızlı ve fazla düştüğünü belirtmiştir. Kadınların hem enformel sektörde istihdamı hem de sosyal güvence ağından yoksunlukları artmıştır (Wadhwa ve Blake, 2021). Ekonomik gelişim düzeyi çoğunlukla kişi-başına düşen gayri safi milli hasıla üzerinden ölçülmektedir. Oysa, eğitim, sağlık hizmetlerine erişim parametreleri göz önünde bulundurularak geliştirilirse, ABD orta düzeyde gelişmiştir (Staudt, 2008).

Demokrasinin farklı prensiplerini ve boyutlarını, boyutlara dair göstergeleri incelediğimizde ülkeler arasında uygulamada farklar görürüz. Liberal demokrasiler arasında en yüksek değerlere sahip 30 demokrasiyi özgürlük, kontrol ve eşitlik prensibini uygulama derecesine göre analiz eden Demokrasi Barometresi Endeksi, 1990-2010 yılları arasındaki en çok eşitlik prensibinin uygulanmasında sorun yaşandığını ortaya koymuştur. Eşitlik prensibi içinde temsil, katılım ve şeffaflık boyutları ve göstergeleri bulunmaktadır. Ekonomik eşitsizlikle toplumsal cinsiyet eşitsizliğine veya ikisinin birleşimine karşılık gelen sorunlar, bu ülkelerin zorlandığı alanlar olmuştur (Bühlmann vd., 2012). 
Demokrasinin Çeşitleri Projesi (V-Dem, 2021) diğer endekslerine toplumsal cinsiyet boyutunu Freedom House Endeksi'ne (2021b) göre oldukça kapsamlı ele almasına rağmen PanDem ve PanBack endekslerinde bu boyut kavramsallaştırma ve ölçüme yansıtılmamıştır. Endeksler çoğunlukla kadınların sayısal siyasi temsili, yani betimleyici temsil kriterlerine dair göstergeler kullanmaktadır. Eşitsizliğin, hem kendi içinde demokrasinin temsil, katılım ve şeffaflık kriterlerinde nasıl tezahür ettiği hem de özgürlük ve kontrol boyutlarıyla etkileşimi göz önünde bulundurulmalıdır (Waylen, 2015). Pandemi ve karantina koşullarında hayatın eve sığdırılması zorunluluğu, eşitsizliğin siyasi temsil sayısına veya daha genel bir bakışla kamusal alanla sınırlanamayacağını, özel alandaki eşitsizliklerin diğer alanlarla bağlantılı olduğunu ortaya koymuştur.

Çalışmamızda siyasi rejimlerle ilgili bibliyometrik analiz sonuçları, Bayesci önsel meta-analiz sonuçları ve endeks değerlerinin incelenmesi Covid19 pandemisi ile birlikte değişen koşulları değerlendirme fırsatı sunmuştur. Sonuç olarak, siyasi sistemler ve pandemi araştırma alanında literatürün gelişiminin takip edilmesi faydalı olacaktır. Araştırmamızda öne çıkan kavramların endekslere yeteri kadar entegre edilmediği dikkati çekmektedir. Kutuplaşma eşitlik ve temsil gibi temel kavramların kesişim noktasında olması itibariyle, liberal demokrasilerin önemli bir unsuru olan uzlaşma ve hoşgörü kültürünü ortadan kaldırma riski taşımaktadır. Endekslerin toplumsal cinsiyet konusunu da göz ardı etmemeleri gerekmektedir. Pandemiyle birlikte, demokrasinin sınandığı alanların artması dolayısıyla toplumsal cinsiyetin siyasi rejim çalışmaları ve kamu politikaları için öneminin artacağı öngörülmektedir. Endekslerin temelini oluşturan liberal demokrasinin hak ve özgürlükler çerçevesinde kavramsallaştırılmasının değişen koşullar uyarınca gözden geçirilmesi önerilmektedir.

\section{Sonuç}

Makalemiz, Covid-19 pandemisi ile siyasi rejimler ve liberal demokrasilerin etkileşimini farklı yöntemler ve yaklaşımlarla araştırmıştır. 2019-2021 arasında WoS veri tabanında taranan, Siyaset Bilimi, Uluslararası İlişkiler ve Bölge Çalışmaları kategorilerinde Covid-19 pandemisi ve siyasi rejimlerin kesiştiği araştırma alanında yayınlanan çalışmaların bibliyometrik analizi 
RStüdyo Bibliometrix programyla gerçekleştirilmiş, kavramsal harita ve Sankey diyagramıla görselleştirilmiştir. Bibliyometrik analize tabi tutulan eserlerin bibliyografik verilerinin olduğu veri setinde en sık tekrarlanan kavram kümeleri demokrasi, toplumsal cinsiyet, demokratik açık ve kutuplaşmadır. Sankey Diyagramı'nda görüldüğü gibi, bu alanda en fazla esere sahip olan $\mathrm{ABD}$ adresli akademisyenlerin toplumsal cinsiyet ve kutuplaşma kavramlarının ön plana çıkmasında rolü olduğu görülmüştür. Sorgu komutunda otoriteryanizm de olmasına rağmen motor ve yön verici bir konu olarak demokrasi kümesinin (kamu politikası kavramıla birlikte) öne çıkması dikkat çekicidir. Bunda Covid-19 pandemisinin demokrasiler için kayda değer imtihan olmasının payı bulunmaktadır. Ayrıca, veri tabanında yer alan eserler sahiplerinin kurum adresleri itibariyle çoğunlukla liberal demokrasiler olmasından dolayı öncelikle bu siyasi rejime dair analizlerin yapılmış olma ihtimali göz önünde bulundurulmalıdır. Siyasi partiler kavramı yoğunluk düzeyi son derece yüksek bir motor kavram olmakla birlikte, bu konunun veri setindeki sıklığının düşük olduğu eklenmelidir. Siyasi partiler yerine demokrasiyle kamu politikası kavramlarının birlikte en sık kullanılan kavramlar olması dikkat çekicidir.

Kutuplaşma kümesi, kutuplaşma ve devlet kavramı birlikte kendi içinde oldukça gelişmiş, araştırma alanındaki başka konularla bağlantılı bir konudur. Araştırma gündeminde toplumsal cinsiyet ile etki kavramı, demokratik açı ile $\mathrm{AB}$ bu alanda yeni ortaya çıkan ya da önemini yitirmekte olan kavram kümelerini temsil etmektedir. Aynı çeyrekteki güç ve siyasi ekonomi kavramlarının veri setinde sıklığı epey düşüktür. Güç ile toplumsal cinsiyet kavramları birbirlerine yakın ölçüde merkezi ve yoğunluk değerlerine sahiptir. Demokratik açık ve siyasi ekonomi kendi içinde oldukça az gelişmiş olmakla birlikte başka kümelerle bağlantılıdır. Kavramsal haritada ilgi çekici bir husus, kutuplaşma, güç, toplumsal cinsiyet, demokratik açık ve siyasi ekonomi konularının yoğunlukları farklı olmakla birlikte, merkezilik düzeyinin yakın olması dolayısıyla sağ çeyreklere yakın olmasıdır. Araştırma alanının gelişiminde bu kavramların sağ çeyrekteki alt motor konulara ya da sağ üst çeyrekteki temel konulara kayması ihtimali göz önünde bulundurulmalıdır.

2019 yılından beri gelişen literatürdeki eser başlıkları, anahtar kelimeler ve yazarların kurum bilgisindeki ülkeler arasındaki bağlar görselleştirilmiştir. ABD, Birleşik Krallık, Avustralya, Japonya, Almanya, Çekya, Kanada, Uk- 
rayna, İtalya, Avusturya, Rusya ve İspanya adresli eserlerin sayısı veri setinde yüksektir. Sankey diyagramında gösterildiği gibi, ABD adresli yayınlar, toplumsal cinsiyet, kutuplaşma, siyasi ekonomi ve demokrasi WoS anahtar kelimelerini sıklıkla kullanmışlardır; tüm başlıkların neredeyse hepsini kullanmışlardır. En sık kullanılan anahtar kelimeler Kanada adresli yayınlarda güç; Almanya adresli yayınlarda demokratik açık ve siyasi ekonomi; Avusturalya adresli yayınlarda siyasi ekonomi; Japonya adresli yayınlarda Avrupa Birliği ve demokratik açı; Çekya adresli yayınlarda siyasi partiler, demokrasi ve AB; Ukrayna adresli yayınlarda siyasi partiler; Birleşik Krallık adresli yayınlarda siyasi ekonomi, etki, kamu politikasıdır. İtalya, Avusturya, Rusya ve İspanya adresli yayınlar anahtar kelimelerle değil, başlıklarla eşleştirilmiştir.

Bibliyometrik analizde demokrasi kavramı motor kavram olarak literatürde öne çıtığ 1 için, ikinci ve üçüncü bölüm pandemi ve demokrasi etkileşimine odaklanmıştır. G7 ülkelerinin 2020 yılı Freedom House Endeksinde siyasi özgürlük ve sivil haklar toplam değerleriyle Covid-19 Dünya Sağlık Örgütü' nün resmi kümülatif vaka ve vefat verileri Bayesci meta-analizle bir ön değerlendirmeye tabi tutulmuştur. "JASP" Ekibi (2020) ile uygulanan Bayesci meta-analizle pandemi ve liberal demokrasi birlikteliğinde etki gücü belirlenmiştir. Önsel meta-analiz sonuçları genel etki büyüklügünün 0,93 olduğunu göstermiştir. Etki gücüne ait huni grafiğinde çalışmamızın orta düzeyde bir yanlılık içerdiği gösterilmiştir. Etki gücüne ait orman grafiğiyle, en yüksek bağıl ağırlığa sahip ülkelerin Kanada ve Japonya oldukları, en düşük bağıl ağırlı̆̆a sahip ülkelerin ABD ve İtalya oldukları görselleştirilmiştir. Freedom House Endeksi endeks değeri arttıkça toplam vaka sayılarında $\% 72,9^{\prime}$ luk azalma, toplam vefat sayılarında ise \%77,3'lük bir azalma olması istatistik olarak tahmin edilmiştir. Ayrıca, toplam vaka sayıları arttıkça \%99,3 oranında vefat sayılarının da artacağı öngörülmüştür. Çalışmamızdaki en önemli kısıt Bayesci (önsel) meta-analiz sonuçlarının nedensel ilişki kurmamasıdır. Bu yüzden, meta-analizlerin gelecekteki zaman kesitlerinde de gerçekleştirilmesi, Bayesci çalışmalar zamana bağlı şekilde tekrarlanarak kümülatif, kıyaslanabilir önsel ve sonsal bilgi kümesi üretilmesi faydalı olacaktır. Ayrıca, G7 ülkesi dışındaki liberal demokrasilerin analizi yapılmamıştır. Toplam demokrasi verilerinde farklar bariz olmadığından güçlü bir çıkarımda bulunmak için yeterli olmayabilir. Ülkeler arasındaki siyasi hak ve özgürlüklerin boyutlarına inilerek Bayesci önsel meta-analiz geliştirilebilir. 
Son olarak, bibliyometrik analiz sonuçları 1şığında, G7 ülkelerinin Freedom House endeksi ile V-Dem Projesi'nin Pandemiyle Bağlantilı İhlaller ve Demokraside Gerileme endekslerinin verileri değerlendirilmiş, ABD'nin endeks değerlerindeki kayda değer kötüleşmeye dikkat çekilmiştir. Pandemi süresince tüm G7 ülkelerinde düşük seviyede demokratik standartlarda gerileme gözlenirken, ABD'de gerileme incelenen 144 ülke arasında 29. sıradadır. ABD'de özellikle resmi kaynakların yanlış bilgilendirmesi, medya özgürlüğünün kısıtlanması ve pandemi kaynaklı önlemlerde zaman kısıtlamasına gitmeme hususlarında demokratik standartlar çiğnenmiştir. Freedom House'a göre, ABD'de pandemi döneminde medya kısıtlamalarının ve polis şiddetinin arttğ̆ görülmüştür.

Siyasi rejimlerle ilgili bibliyometrik analiz sonuçları, Bayesci önsel metaanaliz sonuçları ve endeks değerleri Covid-19 pandemisi ile birlikte değişen koşullara bakma fursatı sunmuştur. Bibliyometrik analiz sonuçlarında yer alan siyasi kutuplaşma, siyasi ekonomi, toplumsal cinsiyet kavramları öncelikle eşitsizlik ve temsil boyutuyla ilgilidir. Genel anlamda liberal demokrasilerde, özellikle ABD'de pandemi dönemi öncesinde, özellikle eşitlik prensibinin uygulamasında eksiklikler tespit edilmiştir. Kutuplaşma liberal demokrasilerin önemli bir unsuru olan uzlaşma ve hoşgörü kültürünü ortadan kaldırma riski taşımaktadır. Kutuplaşma boyutunun endekslere entegre edilmesi faydalı olacaktır. Pandemiyle mücadelede demokrasinin sınandığı alanların artması dolayısıyla, toplumsal cinsiyetin siyasi rejim çalışmaları ve kamu politikaları için öneminin artacağı öngörülmüştür. Değişen koşullar uyarınca, endekslerin temelinde bulunan liberal demokrasinin hak ve özgürlükler çerçevesinde kavramsallaştırılmasının gözden geçirilmesi önerilmiştir.

EXTENDED ABSTRACT

\title{
Covid-19 Pandemic, Political Regimes, and Liberal Democracy
}

\author{
Mehtap Söyler - Mustafa Agah Tekindal
}




\section{İmir Katip Çelebi University}

This article aims at studying the interaction between Covid-19 pandemic, political regimes and liberal democracies through diverse methods. Firstly, it conducts bibliometric analysis of works on the Covid-19 pandemic and political regimes indexed in Web of Science dataset between 2019 and 2021. The conceptual map on this research area demonstrates that democracy is the central and motor theme. Three conceptual sets comprising polarization, gender, and democratic deficit share similar levels of centrality or external links to other concepts, despite their differing levels of density or internal links. The Sankey diagram shows that authors from institutions based in the USA were influential in the making of this research area. Secondly, since democracy emerges as the motor theme in the bibliometric analysis, this article focuses on the interaction between the pandemic and democracy. It sheds light on the struggle against the pandemic in G7 countries, liberal democracies with high levels of economic development. Bayesian (prior) meta-analysis examines the association between the level of Covid-19 cases as well as deaths according to the World Health Organization and the aggregate level of political rights and civil liberties according to Freedom House Index. The association model resulting from meta-analysis indicates medium-level goodness of fit and highlevel effect size, which leads to the prediction that this analysis could be a basis for further studies. Lastly, this article critically assesses G7 countries' democratic performance at the "pandemic exam" by evaluating the Pandemic Violations and Backsliding Indices of Varieties of Democracy Project. The USA is the only country with some, or considerable violations of democratic standards and high levels of pandemic backsliding compared to other G7 countries. In the light of these findings, it is suggested that research at the intersection of political regimes and the pandemic should be tracked and the conceptualization of liberal democracy in indices should be revised in accordance with changing conditions.

In the first section, bibliometric analysis was conducted by using RStudio Bibliometrix package and Biblioshiny interface in order to perform conceptual mapping and to visualize findings. The following search command was formulated for collecting bibliographic data from WoS database: TS=(Covid OR Covid 19 OR pandemic) AND TS=(political regime OR democracy OR 
authoritarianism OR authoritarian OR democratic) AND WC $=$ (political science OR international relations OR area studies). The most frequently used concepts in the bibliographic dataset collected from WoS database are demonstrated in the conceptual map. Four conceptual sets stand out: democracy and public policy, polarization and the state, gender and impact, and democratic deficit and the EU. It is striking that the terms authoritarianism or authoritarian do not appear in the map, although they were included in the advanced search command with other keywords, such as democracy and pandemic. The reason could be the potential challenge posed by the pandemic spefically to democracies. Besides, it should be kept in mind that the majority of works in the dataset were written by authors affiliated to the institutions in liberal democratic countries. It should also be noted that political parties as a topic have a quite high degree of density, but the frequency of this concept in the dataset is very low. It is also remarkable that polarization, power, gender, democratic deficit, and political economy have very similar levels of centrality and are close to the upper-right and lower-right quadrants. The development of this research field should be tracked to check whether these concepts become motor or basic themes in the future.

Since "democracy" emerges as the motor theme in the bibliometric analysis, the second section explores the interaction between the Covid-19 pandemic and liberal democracies with high levels of economic development, the G7 countries. The 2020 political rights and civil liberties values of Freedom House Index and the number of confirmed cases and deaths according to the World Health Organization are employed to conduct the Bayesian (prior) meta-analysis. The effect size of the pandemic-liberal democracy association is determined by "JASP" Team (2020). According to the preliminary information provided by this meta-analysis, the effect size is 0.93 ; the funnel plot indicates medium-level bias; the forest plot demonstrates that the countries with the highest relative weight are Canada and Japan, while the USA and Italy have the lowest relative weight. The most important limitation of this research is that it does not rule out spurious relations. Future research could conduct further meta-analysis comprising data on time sections in the future. Replicating Bayesian studies on a temporal basis generates a set of comparative prior and posterior information, thus producing cumulative knowledge. Besides, the list of liberal democracies is not exhausted with this analysis, fu- 
ture studies could integrate all countries labeled as liberal democracies. In addition to that, moving down from aggregate level to the dimensions of political rights and civil liberties and diversifying the values could be another option to improve the Bayesian (prior) meta-analysis.

In the light of bibliometric analysis, the last section evaluates data in the Freedom House Index and two indices of Varieties of Democracy Project (VDem), the Pandemic Violations of Democratic Standards Index (PanDem) and the Pandemic Backsliding Index (PanBack), with respect to the G7 countries. The results show that even in liberal democracies with high levels of economic development, it is not safe to claim that democratic standards will certainly be guaranteed. Data point to a remarkable difference between the USA and other G7 countries. The level of pandemic violations of democratic standards in the USA (0.3) refers to some violations but approaches to the 3.5 threshold of major violations. The backsliding in the USA ranks the $29^{\text {th }}$ among 144 countries with regard to the deterioration of democracy levels. VDem Project reports that violations in the USA occurred especially in the realm of official disinformation, violation of media freedom, and no time limit in pandemic related measures. Freedom House reports increase in media restrictions and police violence. In contrast to bibliometric analysis results, polarization and gender are not addressed in indices. In liberal democracies in general, especially in the USA, the principle of equality and representation have been the most challenging aspects of norm implementation before the pandemic broke out in 2020. This study suggests that research on the connection of political systems and the pandemic should be expanded. Polarization and inequality pose a serious threat to democracy. The importance of gender for democracy its relevance to research on political regimes and public policy have increased during pandemic. The conceptualization of liberal democracy embedded in indices should be revised in accordance with changing conditions.

\section{Kaynakça / References}

Acemoğlu, D., Naidu, S., Restrepo, P., ve Robinson, J. A. (2019). Democracy does cause growth Suresh Naidu Pascual Restrepo. Journal of Political Economy, 127(1), 47-100.

Akaike, H. (1974). A new look at the statistical model identification. IEEE Transaction on Automatic Control, 19(6), 716-724. 
Aria, M., ve Cuccurullo, C. (2017). An R-tool for comprehensive science mapping analysis. Journal of Informetrics, 11(4), 959-975. 10 Nisan 2020 tarihinde https://www.bibliometrix.org/vignettes/Introduction_to_bibliometrix.html adresinden erişildi.

Aria, M., ve Cuccurullo, C. (2020). Bibliometrix. 10 Nisan 2020 tarihinde https://www.bibliometrix.org/vignettes/Introduction_to_bibliometrix.html adresinden erişildi.

Aria, M., Misuraca, M., ve Spano, M. (2020). Mapping the evolution of social research and data science on 30 years of Social Indicators Research. Social Indicators Research, 149, 803-831.

Benedikt Frey, C., Chen, C., ve Presidente, G. (2020). Democracy, culture, and contagion: Political regimes and countries responsiveness to covid-19. Covid Economics, 18, 1-20.

Bol, D., Giani, M., Blais, A., ve Loewen, P. J. (2020). The effect of COVID-19 lockdowns on political support: Some good news for democracy? European Journal of Political Research, 1-9. https://doi.org/10.1111/1475-6765.12401. 12 Aralık 2020 tarihinde https://ejpr.onlinelibrary.wiley.com/doi/10.1111/1475-6765.12401 adresinden erişildi.

Bolstad, W. M., ve Curran, J. M. (2016). Introduction to bayesian statistics. New Jersey: Wiley.

Bühlmann, M., Merkel, W., Müller, L., ve Weßels, B. (2012). The democracy barometer: A new instrument to measure the quality of democracy and its potential for comparative research. European Political Science, 11(4), 519-536.

Callon, M., Courtial, J. P., ve Laville, F. (1991). Co-word analysis as a tool for describing the network of interactions between basic and technological research: The case of polymer chemsitry. Scientometrics, 22, 155-205.

Crouch, C. (2004). Post-democracy. Cambridge: Polity Press.

Crozier, M. J., Huntington, S. P., ve Watanuki, J. (1975). The crisis of democracy: Report on the governability of democracies to the trilateral commission. New York.

Dahl, R. A. (1971). Polyarchy: Participation and opposition. New Haven: Yale University Press.

DerSimonian, R., ve Laird, N. M. (2015). Meta-analysis in clinical trials revisited. Contemporary Clinical Trials, 45, 139-145.

Druckman, J. N., ve Sharrow, E. A. (2020). Public opinion, crisis, and vulnerable populations: The case of title ix and covid-19. Politics and Gender, 16(4). 
Duval, S. J., ve Tweedie, R. L. (2000). Trim and fill: a simple funnel-plot-based method of testing and adjusting for publication bias in meta-analysis. Biometrics, $56(2), 455-463$.

Edgell, A. B., Lührmann, A., Seraphine, F., Maerz, J. L., Grahn, S., Good God, A. F., Lundstedt, M., Natsika, N., Kolvani, P., Bederke, P., Pillai, S., Kaiser, S., Alijla, A., Fernandes, T., Tung, H., Wilson, M. and Lindberg, S. I. (2020). Pandemic backsliding: Democracy during covid-19 (pandem). Version 5. Varieties of Democracy (V-Dem) Institute, 5 Ocak 2021 tarihinde www.v-dem.net/en/ourwork/research-projects/pandemic-backsliding/ adresinden erişildi.

Freedom House. (2020). Democracy under lockdown. the impact of covid-19 on the global struggle for freedom. 9 Şubat 2021 tarihinde https://freedomhouse.org/report/special-report/2020/democracy-under-lockdown adresinden erişildi.

Freedom House. (2021a). Freedom in the world data sources. Tarihinde 9 Şubat 2021 tarihinde https://freedomhouse.org/report/freedom-world adresinden erişildi.

Freedom House. (2021b). Freedom in the world research methodology. 9 Şubat 2021 tarihinde https://freedomhouse.org/reports/freedom-world/freedom-world-research-methodology adresinden erişildi.

Huntington, S. P. (1991). The third wave: Democratization in the late 20th century. Journal of Democracy, 2(1), 12-34.

Hurvich, C.M., Tsai, C.L. (1989). Regression and time series model selection in small samples. Biometrika, 76(2), 297-307.

Kadar, A. (2020). In its nature-how stealth authoritarianism keeps stealing along during the pandemic, and How Can it be Stopped?. Journal of Human Rights Practice, 12(2),293-300.

Krause, W., ve Merkel, W. (2018). Crisis of democracy? Views of experts and citizens. W. Merkel ve S. Kneip (Ed.), Democracy and Crisis: Challenges in Turbulent Times içinde (s. 31-48). Cham: Springer Verlag.

Lipset, S. M. (1959). Some social requisites of democracy : Economic development and political legitimacy. American Political Science Review, 53(1), 69-105.

Lührmann, A., Mechkova, V., Dahlum, S., Maxwell, L., Olin, M., Petrarca, C. S. and Lindberg, S. I. (2018). State of the world 2017: autocratization and exclusion? Democratization, 25(8), 1321-1340.

Maerz, S. F., Lührmann, A., Hellmeier, S., Grahn, S., ve Lindberg, S. I. (2020). State of the world 2019: autocratization surges-resistance grows. Democratization, 27(6), 909-927.

Mouffe, C. (2000). The democratic paradox. Londra: Verso. 
Patsopoulos, N. A., Evangelou, E., ve Ioannidis, J. P. A. (2008). Sensitivity of betweenstudy heterogeneity in meta-analysis: proposed metrics and empirical evaluation. International Journal of Epidemiology, 37(5), 1148-1157.

Pepinsky, T. B. (2020). Political economy and democratic capacity to respond to pandemics. 9 Aralik 2020 tarihinde https://items.ssrc.org/covid-19-and-the-social-sciences/democracy-and-pandemics/political-economy-and-democratic-capacity-to-respond-to-pandemics/ adresinden erişildi.

Petersohn, S., ve Heinze, T. (2018). Professionalization of Bibliometric research assessment. Science and Public Policy, 45(4), 565-578.

Przeworski, A., Alvarez, M., Cheibub, J. A., ve Limongi, F. (2000). Democracy and development: political institutions and material wellbeing in the world (1950-1990). Cambridge: Cambridge University Press.

Reny, T. T. (2020). Masculine norms and infectious disease: The Case of COVID-19. Politics and Gender, 16(4).

Rodriguez, C. G., Gadarian, S. K., Goodman, S. W., ve Pepinsky, T. B. (2020). Morbid polarization: Exposure to COVID-19 and partisan disagreement about pandemic response. PsyArXiv Preprints, 1-45. 10 Aralık 2020 tarihinde https://psyarxiv.com/wvyr7/ adresinden erişildi.

Schedler, A. (2007). Electoral authoritarianism. The SAGE Handbook of Comparative Politics içinde (C. 35, s. 381-394). Boulder, Colo.: Lynne Rienner Publishers.

Schwarz, G. (1978). Estimating the dimensions of a model. Annals of Statistics, 6(2), 461-464.

Smith, J. C. (2020). Where are the women? Descriptive representation and covid-19 in U.K. Daily Press Briefings. Politics and Gender, 16(4), 991-1000.

Sonn, J. W., ve Lee, J. K. (2020). The smart city as time-space cartographer in COVID19 control: the South Korean strategy and democratic control of surveillance technology. Eurasian Geography and Economics, 61(4-5), 482-492.

Staudt, K. (2008). Politics, Gender, and Concepts. G. Goertz ve A. G. Mazur (Ed.), Politics, Gender, and Concepts içinde (s. 136-158). Cambridge, New York: Cambridge University Press.

Sutton, A. J., Abrams, K. R., ve Jones, D. R. B. (2001). An illustrated guide to the methods of meta-analysis. Journal of Evaluation in Clinical Practice, 7, 135-148.

UN Food and Agriculture Organization. (2021). The State of Food Security and Nutrition in the World 2020. 2 Şubat 2021 tarihinde http://www.fao.org/3/ca9692en/online/ca9692en.html\#chapter-Key_message adresinden erişildi. 
Varieties of Democracy (V-Dem). (2021). Pandemic backsliding project (pandem). 12 Şubat 2021 tarihinde https://www.v-dem.net/en/analysis/PanDem/ adresinden erişildi.

Wadhwa, D., ve Blake, P. (2021). 2020 Year in review: The impact of covid-19 in 12 charts. 9 Şubat 2021 tarihinde, https://blogs.worldbank.org/voices/2020-year-review-impact-covid-19-12-charts adresinden erişildi

Waylen, G. (2015). Engendering the crisis of democracy. Government and Opposition, 50(3), 495-520.

Web of Science (WoS). (2020). Main Page. 5 Şubat 2021 tarihinde https://apps.webofknowledge.com/WOS_GeneralSearch_input.do?product=WOS\&search_mode=GeneralSearch\&SID=D4hORYNJKgXsyX8EkdW\&preferencesSaved $=$ adresinden erişildi.

WHO. (2021). WHO coronavirus disease (COVID-19) Dashboard. 9 Şubat 2021 tarihinde https://covid19.who.int adresinden erişildi.

Wong, M.C.S., Wong, E.L.Y. Huang, Junjie, Cheung, A.W.L., Law, K., Chong, M. K. C., vd. (2021), Acceptance of the COVID-19 vaccine based on the health belief model: A population-based survey in Hong Kong, Vaccine, 39 (7), 1148-1156.

\section{Kaynakça Bilgisi / Citation Information}

Söyler, M. ve Tekindal, M. A. (2021). Covid-19 pandemisi, siyasi rejimler ve liberal demokrasi. OPUS-Uluslararası Toplum Araştırmaları Dergisi, 17(Pandemi Özel Sayıs1), 3832-3868. DOI: 10.26466/opus. 885216 